\title{
Improving the measures of real earnings management
}

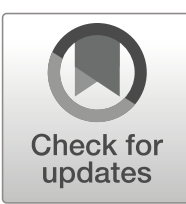

\section{Anup Srivastava ${ }^{1}$}

Published online: 31 July 2019

(C) The Author(s) 2019

\begin{abstract}
Firms often change their operating policy to meet a short-term financial reporting target. Accounting researchers call this opportunistic action real earnings management (REM). They measure REM by the difference between a firm's costs and those reported by its industry peers. Firms that pursue distinct competitive strategies also display different cost patterns than peers. However, the models that measure REM do not control for differences in competitive strategy. Hence a researcher can misinterpret a cost difference that stems from a firm's competitive strategy as REM. The researcher would also find a spurious correlation between earnings management and a firm characteristic that varies with competitive strategy. A cause or effect relationship with earnings management could be wrongfully inferred. I suggest improvements in measurement models to avoid misspecification.
\end{abstract}

Keywords Competitive strategy $\cdot$ Intra-industry homogeneity $\cdot$ Real earnings management - Intangible investments

JEL classification $\mathrm{M} 13 \cdot \mathrm{M} 41 \cdot \mathrm{M} 43 \cdot \mathrm{C} 12 \cdot \mathrm{C} 13 \cdot \mathrm{G} 32$

\section{Introduction}

Graham et al. (2005) find that chief financial officers are willing to change their firms' operating policies to meet a financial reporting target, implying that earnings management extends beyond accruals manipulation and includes real activities. For example, managers could temporarily cut research and development (R\&D) outlays to show a profit instead of a loss. Studies call such a manipulation real earnings management

Anup Srivastava

anup.srivastava@ucalgary.ca

1 Haskayne School of Business, University of Calgary, Scurfield Hall, 2500 University Dr NW,

Calgary, AB T2N 1N4, Canada 
(REM) and measure its extent by the difference between the firm's costs and those reported by its industry peers (Roychowdhury 2006). The literature has made considerable progress in measuring accrual manipulation, but REM estimation models remain rudimentary. ${ }^{1}$ Researchers continue to use the original models proposed by Roychowdhury (2006), despite the problems identified in recent studies (Siriviriyakul 2015; Cohen, et al. 2016). ${ }^{2}$ I investigate three questions: (1) Are REM models misspecified? (2) Could researchers draw incorrect inferences because of the misspecifications? (3) Can those models be improved and, if so, how?

I show that REM models cannot distinguish between a firm's earnings management and its competitive strategy, because both can entail different levels of costs than industry peers. Consequently, researchers could erroneously infer REM if same-industry firms pursue different strategies. I find that variations in competitive strategies within industries are large enough to cause incorrect inferences about the presence and extent of earnings management. Furthermore, competitive strategy is associated with commonly studied accounting and finance variables, such as capital structure, corporate governance, executive compensation, and disclosure policy. Researchers can therefore document spurious correlations between earnings management and strategy-driven firm characteristics. I suggest improvements in REM estimation models to address this problem.

Roychowdhury (2006) proposes four models to measure REM, each focused on a different component of operating income. Two of these models interpret negative abnormal levels of R\&D and selling, general, and administrative (SG\&A) expenses as cutbacks of discretionary costs. The third model considers positive abnormal production cost [cost of goods sold [(COGS) plus changes in inventory] to be overproduction. The fourth model regards abnormal cash flow from operations as a sign of earnings management. ${ }^{3}$ Abnormal values for each of the four variables are obtained from linear regression models at the industry-year level and rely on two assumptions. First, all firms in an industry have the same cost and cash flow patterns when they are not managing earnings. Second, sales revenue is the sole driver of costs and profitability in the normal course of business. (SG\&A and R\&D models make this assumption using past revenue.) Researchers then, depending on the model, deem as abnormal the portion of costs or cash flows that are unrelated to current or past sales.

I show that the two assumptions underlying the estimation models are systematically violated. The cost patterns and cash profitability of firms in a given industry could differ because firms are in different stages of their life cycles (Miller and Friesen 1984; Dickinson 2011) or they adopt dissimilar business models at the time of their formation (Stinchcombe 1965). Young firms invest more in intangibles to create product differentiation or cost advantage (Porter 1980). In addition, firms listed in the last 25 years or

\footnotetext{
${ }^{1}$ See, for example, DeFond and Jiambalvo (1994), Dechow et al. (1995), Hribar and Collins (2002), Kothari et al. (2005), and Owens et al. (2017).

${ }^{2}$ See, for example, Doyle et al. (2013), Franz et al. (2014), Kim and Park (2014), Chen et al. (2015b), Chen et al. (2015a), and Ali and Zhang (2015).

${ }^{3}$ Cutting discretionary costs could increase cash flow, but overproduction drives it down. Most studies conclude that firms engage in REM by cutting discretionary costs, not by overproduction. See, for example, McInnis and Collins (2011, pp. 231, 232), Kim and Park (2014, p. 388), and Chan et al. (2015, p. 157). Another possible explanation is that discretionary costs are easier to manipulate than production expenses.
} 
so have capitalized on the progress in information technology to offer innovative products and enhanced services to customers (Shapiro and Varian 1998). Hence younger cohorts are more likely to pursue customer intimacy and product leadership strategies than older cohorts at the same stage of their life cycle (Treacy and Wiersema 1993). Pursuing those strategies requires high levels of intangible inputs, which are reported in R\&D and SG\&A (Brown and Kapadia 2007; Govindarajan and Srivastava 2016). I find that younger cohorts incur larger R\&D and SG\&A expenses in the normal course of operations than older cohorts in the same industry. Furthermore, older cohorts show higher levels of cash profitability than do younger cohorts, which typically incur losses. So the old and new cohorts within industries differ in their cost and profitability patterns.

The second assumption, that current or past sales is the sole driver of nonmanipulated costs and profitability, is systematically violated in three of the four REM models. Firms make cost decisions according to their competitive strategy. For example, firms invest in innovation, strategy, market research, customer and social relationships, computerized data and software, brands, and human capital to reap longterm rewards (Wernerfelt 1984; Peteraf 1993; Eisfeldt and Papanikolaou 2013). ${ }^{4}$ A firm's plan for its future market share, revenues, or profits thus must be a significant determinant of its investment policy. A discretionary cost model that is based solely on past revenues should therefore be misspecified, because it excludes major determinants of planned investments. In contrast, a production cost model would be well specified because COGS, the main component of production cost, is matched to current revenues by accounting convention. ${ }^{5}$

I find that the residuals from discretionary cost models (the portion of costs that is unrelated to current revenues) are large and strongly associated with future revenue growth. Discretionary cost models thus measure REM with errors that reflect long-term investments. Furthermore, residuals display the same cohort patterns as the reported discretionary costs - they increase from the oldest to the youngest cohorts. Because regression residuals must add up to zero, the oldest cohorts show large negative residuals, while the youngest cohorts display large positive values. A researcher would conclude that the oldest cohorts opportunistically cut discretionary costs and the youngest cohorts overinvest in intangibles.

The production cost model is better specified than the discretionary cost model and yields smaller residuals, because COGS is highly matched to current revenues. ${ }^{6}$ Also, the difference between the residuals of the youngest and the oldest cohorts is much smaller for the production cost model than for the discretionary cost models. Thus the youngest and the oldest cohorts show no significant difference in earnings management by overproduction but appear to significantly differ in earnings management by discretionary cost curtailment. This pattern is noteworthy because studies typically find

\footnotetext{
${ }^{4}$ Sougiannis (1994) and Lev and Sougiannis (1996) find that R\&D investments increase future earnings for up to five years. Banker et al. (2011) and Enache and Srivastava (2018) find that SG\&A expenses are associated with earnings for three years into the future.

${ }^{5}$ Roychowdhury (2006, p. 350) shows the correlation of current revenues with SG\&A (0.39) is significantly lower than with production cost $(0.95)$. The correlation of operating cash flow with revenues is even smaller (0.11).

${ }^{6}$ Over $60 \%$ of the variation in discretionary costs is unexplained by the model (Roychowdhury 2006, p. 349). This is unlike the production cost model, which exhibits R-squared of $89 \%$.
} 
significant earnings management using discretionary cost models but not with production cost models. Stated differently, the literature shows widespread earnings management using measures that are obtained from under-specified models. But the same studies do not report significant results with measures of better-specified models. Furthermore, earlier studies typically find higher REM for large, low-growth, and highly profitable firms, which are the characteristics of older cohorts. ${ }^{7}$ In effect, those studies conclude that older cohorts manage earnings by cutting discretionary costs when the routine business practice of those firms may be to invest less in research and development and intangibles.

The above tests do not rule out the possibility that older cohorts manage earnings to a greater extent than do younger cohorts. Three tests negate this proposition. First, older cohorts are characterized by low growth and positive cash flows. Therefore they have the least incentive to mislead external capital providers, which is arguably the strongest motive for earnings management (Dechow and Skinner 2000). Second, the serial correlation of REM proxies is as high as $0.5-0.7$, indicating persistence in firms' distinctive characteristics (Siriviriyakul 2015). This high persistence shows the stability of firms' competitive strategies (Stinchcombe 1965; Porter 1980) and is inconsistent with the idea that REM is a temporary deviation from a firm's optimal business practice and that it should reverse in the next period to catch up with necessary expenses. ${ }^{8}$ Third, the oldest cohorts continue to show the largest profits year after year. This pattern contradicts the proposition that the oldest cohorts continually manipulate their operations, because a prolonged deviation from the optimal business practice must be followed by reduction in profits. ${ }^{9}$

In addition, the oldest cohorts' normal discretionary costs (those explained by the estimation models) are also lower than those of the youngest cohorts. These findings lead me to conclude that the oldest cohorts' distinct ways of doing business are misinterpreted by the current models as real earnings management. Members of the oldest cohorts have survived for more than 40 years. They must have competed successfully against each other and the nonsurviving firms by following superior strategies, creating better products, or establishing more stable markets and customer bases, which now enables them to earn economic rents without having to invest as much in intangibles as younger cohorts (Amit and Schoemaker 1993; Agarwal and Gort 2002). New players, in contrast, must spend higher amounts on innovation, strategy, advertising, customer relationships, and brands to build competitive advantages or to gain from recent technological advances (Porter 1980; Shapiro and Varian 1998). These differences in competitive strategies of the oldest and youngest cohorts, in conjunction with the under-specification of REM estimation models, lead to the appearance that the oldest cohorts underinvest in intangible assets.

\footnotetext{
${ }^{7}$ See, for example, Kim and Park (2014, p. 381), Cohen et al. (2016, p. 42), and Cheng et al. (2016, p. 1062).

${ }^{8}$ In that case, the serial correlation in abnormal costs should be negative, not positive.

${ }^{9}$ Otherwise, any action that reduces costs and improves profitability, such as enhancing production and distribution efficiencies and closing unprofitable divisions, should be considered real earnings management. But why those actions should be considered suboptimal or opportunistic is unclear.
} 
The main takeaway from the paper is that competitive strategy is an omitted variable in REM estimation models that should be included in the first-stage models. ${ }^{10}$ The empirical proxies for competitive strategy are not available in financial reports, which is a major limitation of accounting (Lev and $\mathrm{Gu} 2016$ ). I propose a sequence of corrective steps based on the available financial statement variables. First, I assume that a firm's competitive strategy relates to its opportunity set. Thus, in the first-stage estimation, I include the proxies for opportunity set, namely, size, past profitability, and growth (Gunny 2010). Second, I assume that firms spend on intangibles to generate current revenues as well as to secure future benefits. Hence I include future revenues in the estimation models. Third, I control for the firm's own past expenses to identify deviations from its routine behavior (Gunny 2010). Even if successfully applied, these three steps cannot correct for a firm's optimal business response to a new economic shock in the measurement year. That response would appear as a deviation from the firm's past expenses, which could be misinterpreted as real earnings management. Researchers can avoid this error by using a cohort adjustment, based on the assumption that firms in similar life-cycle stage and with similar technological vintage experience similar economic shocks. ${ }^{11}$ I subtract the costs of a similar-size firm belonging to the same industry cohort from the costs of a given firm to estimate its abnormal behavior.

I demonstrate that each sequential step mitigates the measurement errors in REM proxies and reduces the portion of costs considered manipulative. Mitigation with each step, however, differs across proxies. The inclusion of one-year-forward revenues more effectively mitigates the errors for SG\&A than for the production cost model, because abnormal SG\&A is strongly correlated with future revenue growth and abnormal COGS is not. Cohort adjustment has the largest effect on R\&D models, suggesting that firms with similar technology vintage and in similar stage of life cycle spend similar amounts on R\&D. The steps I propose could change the inferences of studies, such as that of Kim and Park (2014).

My paper makes three contributions to the literature. First, it adds to understanding of the earnings management phenomenon as measured by the current REM models. I show that the models ignore the relation between a firm's competitive strategy and its costs, leading researchers to misinterpret strategy-related cost difference as earnings management. My findings are consistent with the ideas of Dechow et al. (2010) that earnings properties are determined by both fundamental performance and accounting practice and of Ball (2013) that researchers often find earnings management when no other party with greater information and incentive detects that pattern.

Second, I propose enhancements in the estimation models to lower the competitive strategy-related measurement errors in earnings management proxies. Any hypothesis test of an incentive for earnings management is a joint test of the validity of the researcher's first-stage model and the relation between the incentive and earnings management. The enhancements I propose should improve the reliability of future tests about earnings management. As such, my contribution is analogous to that of Dechow et al. (1995), Kothari et al. (2005), and Owens et al. (2017) in improving the

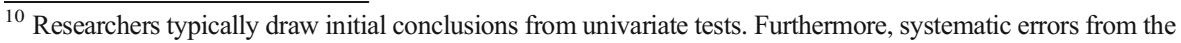
first-stage estimation can cause erroneous conclusions in the second-stage tests (Larcker and Richardson 2004; Kothari et al. 2005).

${ }^{11}$ Technological vintage refers to the initial production technology the firm adopts at the time of its formation that becomes a persistent part of its competitive strategy (Stinchcombe 1965).
} 
measurement of discretionary accruals. Nevertheless, I caution researchers against mechanically applying the corrective steps I propose. These steps would overcorrect for errors when the incentive for earnings management varies with the firm's opportunity set, when the firm routinely manages earnings, or when the members of the firm's industry cohort manage earnings to an equal extent.

Third, results of this paper can be generalized to any model that estimates a firm's abnormal, manipulative, or suboptimal behavior by the uniqueness of its characteristics vis-à-vis industry peers. I show that the oldest and youngest cohorts in an industry often differ in their competitive strategies, leading to systematic differences in their strategyrelated financial characteristics. Thus cohort adjustment must be applied to any industry-based measurement of suboptimal or manipulative behavior.

The rest of the paper is organized as follows. Section 2 describes the literature on real earnings management and explains the estimation models and measurement of variables. Section 3 examines the violations of the two assumptions underlying the Roychowdhury (2006) models. Sections 4 and 5 investigate whether model misspecifications can lead to incorrect inferences about the presence and the extent of real earnings management. Section 6 proposes a sequence of improvements in the models. Section 7 concludes.

\section{Prior research, description of models, and measurement of variables}

Healy and Wahlen (1999, p. 368) state that "[e]arnings management occurs when managers use judgment in financial reporting and in structuring transactions to alter financial reports to either mislead some stakeholders about the underlying economic performance of the company or to influence contractual outcomes that depend on reported accounting numbers." Managers can manipulate not only financial reports but also operating and financing activities to meet reporting targets. ${ }^{12}$ This idea is confirmed in the Graham et al. (2005) survey of financial executives, which finds that chief financial officers are willing to cut discretionary costs, such as R\&D and advertising, to show higher earnings in the short term. Roychowdhury (2006) proposes an innovative method to detect such opportunism.

Roychowdhury (2006) suggests that deviations in production costs and discretionary costs from otherwise optimal operating decisions represent managers' attempt to manipulate earnings. He reasons that lower discretionary costs, compared with industry peers [identified by two-digit Standard Industrial Classification (SIC) code], could indicate the reduction of soft discretionary costs. He also posits that higher production costs, relative to peers, represent overproduction of goods. He further argues that manipulation of real activities affects operating cash flow, though the direction of the effect is ambiguous. Many subsequent studies associate abnormal operating cash flow with REM, consistent with the idea that curtailment of discretionary costs increases operating cash flow.

\footnotetext{
${ }^{12}$ Managers liquidate inventory (Dhaliwal et al. 1994); sell long-term assets (Bartov 1993; Herrmann et al. 2003); reduce discretionary costs (Bushee 1998; Baber et al. 1991), R\&D (Cohen et al. 2010), and sales prices (Jackson and Wilcox 2000); structure financial transactions (Barton 2001; Pincus and Rajgopal 2002; Dechow and Shakespeare 2009), leases (Imhoff and Thomas 1988), and debt-equity swaps (Hand 1989); and indulge in mergers and acquisitions (Ayers et al. 2002) and stock repurchases (Hribar et al. 2006) to manage earnings.
} 
Roychowdhury (2006) models require two assumptions. First, in the normal course of business, all firms in a given industry need the same level of discretionary costs and production costs, and they generate the same levels of cash operating profits. (All variables are scaled by total assets at the beginning of the year.) Second, either current or past revenue is the sole determinant of optimal costs. Based on these assumptions, Roychowdhury (2006) measures a firm's deviations from its optimal outlays by the residuals from the regressions of SG\&A, R\&D, production costs, and operating cash flow on current or past revenues estimated by industry and year. He finds that regression residuals are associated with the frequency of meeting earnings benchmarks. He therefore reasons that the regression residuals represent a firm's suboptimal behavior to manipulate financial reports. Roychowdhury's models continue to be widely used in the literature, despite enhancements proposed by subsequent studies (e.g., Gunny 2010).

\subsection{Measurement of real earnings management}

Consistent with Roychowdhury (2006), I measure discretionary costs by $S G \& A$ (Compustat XSGA) and $R \& D(\mathrm{XRD})$. ProductionCost is calculated by adding changes in inventory (INVT) to cost of goods sold (COGS). Cash flow from operations (OANCF) is referred to as OperatingCashFlow. ${ }^{13}$ All variables are scaled by total assets at the beginning of the year (AT).

To determine overproduction, I follow Roychowdhury (2006) and estimate the following cross-sectional regression for each industry (two-digit SIC code) and year.

$$
\begin{aligned}
& \text { ProductionCost }_{\mathrm{i}, \mathrm{t}}=\beta_{1}+\beta_{2} \times \frac{1}{\text { Total Assets }_{\mathrm{i}, \mathrm{t}-1}}+\beta_{3} \times \frac{\text { Sales }_{\mathrm{i}, \mathrm{t}}}{\text { Total Assets }_{\mathrm{i}, \mathrm{t}-1}}+\beta_{4} \times \frac{\Delta \text { Sales }_{\mathrm{i}, \mathrm{t}}}{\text { Total Assets }_{\mathrm{i}, \mathrm{t}-1}} \\
& +\beta_{5} \times \frac{\Delta \text { Sales }_{\mathrm{i}, \mathrm{t}-1}}{\text { Total Assets }_{\mathrm{i}, \mathrm{t}-1}}+\epsilon_{\mathrm{i}, \mathrm{t}}
\end{aligned}
$$

where $\Delta$ Sales represents changes in revenues. The residual estimated on a firm-year basis represents a manipulation of the production schedule. The more positive the residual, the higher the manipulation, assuming that firms increase their production levels to spread fixed costs over a larger number of units to show higher profit margins.

To determine curtailment of discretionary costs, the following cross-sectional models are estimated for each industry and year (Roychowdhury 2006).

$$
{\operatorname{SG} \& A_{i, t}}=\beta_{1}+\beta_{2} \times \frac{1}{\text { Total Assets }_{i, t-1}}+\beta_{3} \times \frac{\text { Sales }_{i, t-1}}{\text { Total Assets }_{i, t-1}}+\epsilon_{i, t}
$$

and

$$
{\mathrm{R} \& D_{i, t}}_{i}=\beta_{1}+\beta_{2} \times \frac{1}{\text { Total Assets }_{i, t-1}}+\beta_{3} \times \frac{\text { Sales }_{i, t-1}}{\text { Total Assets }_{i, t-1}}+\epsilon_{i, t}
$$

\footnotetext{
${ }^{13}$ My definitions differ from those of Roychowdhury (2006) in one principal respect. Roychowdhury adds R\&D and advertising to SG\&A, but I do not, because Compustat's variable for SG\&A (XSGA) includes advertising and R\&D expenses. I also do not separately examine advertising expenses, because they are economically insignificant compared with R\&D and SG\&A (Enache and Srivastava 2018).
} 
The residuals are the inverse measures of manipulation of discretionary costs. (The model for R\&D is the same as that of Roychowdhury (2006, p. 351, footnote 24).) The more negative the SG\&A and R\&D residuals, the higher the curtailment of discretionary costs.

Abnormal OperatingCashFlow is measured by estimating the following crosssectional model by industry-year (Roychowdhury 2006).

$$
\begin{aligned}
\text { OperatingCashFlow }_{\mathrm{i}, \mathrm{t}}= & \beta_{1}+\beta_{2} \times \frac{1}{\text { Total Assets }_{\mathrm{i}, \mathrm{t}-1}}+\beta_{3} \times \frac{\text { Sales }_{\mathrm{i}, \mathrm{t}}}{\text { Total Assets }_{\mathrm{i}, \mathrm{t}-1}} \\
& +\beta_{4} \times \frac{\Delta \text { Sales }_{\mathrm{i}, \mathrm{t}}}{\text { Total Assets }_{\mathrm{i}, \mathrm{t}-1}}+\epsilon_{\mathrm{i}, \mathrm{t}}
\end{aligned}
$$

The residuals represent the curtailment of sales expenses.

\subsection{Financial characteristics}

In addition to costs, I examine variations in financial characteristics of firms in the same industry. I consider the market value of equity, lagged return on assets (ROA), and the market-to-book ratio as proxies for firm size, nonmanipulated profitability, and growth, respectively. I measure profitability by the earnings-to-price ratio and the return on assets. A firm is assumed to have just missed its earnings target if it reports a loss and the ratio of net income to beginning-of-year total assets lies between zero and - $1 \%$. A firm is assumed to have just met the earnings target if its ratio of net income to beginning-of-year total assets is between zero and $1 \%$. I also calculate these variables based on changes in earnings. If the change is negative but greater than $-1 \%$ of beginning-of-year total assets, the firm is presumed to have just missed showing improvement in profitability. If the firm reports an increase in net income greater than zero but less than $1 \%$ of beginning-of-year total assets, it is presumed to have just shown improvement in profitability.

\section{Violations of the two assumptions underlying real earnings management models}

This section investigates violations of the two principal assumptions underlying the Roychowdhury (2006) models: the intra-industry homogeneity assumption and the current or past revenues being the sole determinant of firms' optimal costs.

I exclude financial firms, beginning with SIC code 6, because the traditional cost classifications (COGS versus SG\&A accounts) do not apply to them. The remaining firms are categorized by industry based on two-digit SIC codes, consistent with Roychowdhury (2006) and the ensuing studies. Roychowdhury's models, by construction, measure variations among the characteristics of firms in a given industry and year. I test my thesis, that these models could be misspecified, by using 2014 as a representative year. In untabulated tests, I obtain similar results by examining other years from 2010 to 2013. 
The listing year is the first year in which a firm has valid data in Compustat. ${ }^{14}$ All firms listed in a common year are referred to as members of a listing cohort. Firms listed before 1950 are assumed to have a listing year of 1950, given the limitations in the Compustat database. Listing vintage (ListingVintage) is measured in years by subtracting the listing year from 2014. Either listing vintage or listing year is used to identify a cohort, because all observations pertain to the same year. Each firm-year observation requires data from the past two years for estimating real earnings management models, so the latest listing year is $2012 .{ }^{15} \mathrm{I}$ end up with 4,929 firm-year observations with valid data, all pertaining to fiscal year 2014 .

\subsection{Violation of the intra-industry homogeneity assumption}

Many studies, not just those on real earnings management, assume similarity in products, services, and production functions of same-industry firms (Guibert et al. 1971). Recent literature questions this assumption and shows that its violation leads to biased estimates of discretionary accruals (Hribar and Nichols 2007; Dopuch et al. 2012; Ecker et al. 2013; Collins et al. 2014; Owens et al. 2017). Models for estimating discretionary accruals have evolved based on these studies (DeFond and Jiambalvo 1994; Dechow et al. 1995; Hribar and Collins 2002; Kothari et al. 2005). Yet the implications of its violation are less well understood for REM models.

\subsubsection{Systematic differences in the characteristics of successive listing cohorts}

I hypothesize that the financial and cost characteristics of same-industry firms could differ by listing cohorts. Srivastava (2014) supports this idea for the overall set of listed firms. He shows that successive listing cohorts display increasing intangible intensity, measured by R\&D, SG\&A expenditures, and market-to-book ratios. Such inter-cohort differences do not dissipate with time, indicating that those differences reflect more permanent differences in cohorts' business models, not just temporary differences in cohorts' life-cycle stages. (See Fig. D1 of Brown and Kapadia (2007) and Fig. 3 of Srivastava and Tse (2016).) Similar patterns are observed in some empirical manifestations of competitive strategy, such as profitability, survival rates, special items, earnings volatility, and market-to-book ratio.

I confirm that the patterns documented previously hold for the 2014 firm sample. Panel A of Table 1 presents the pooled average characteristics as well as the number of firm-year observations by listing vintage. I classify firms into four quartiles by their listing vintage, with the highest and lowest listing vintage representing the oldest and youngest cohort, respectively. I then calculate the average characteristics for the youngest and oldest cohorts for the pooled sample. Panel B shows that $R \& D$ and

\footnotetext{
${ }^{14}$ The Compustat listing year is a few years ahead of the listing year obtained from the Center for Research in Security Prices (CRSP) database. I use the Compustat listing year to maintain consistency with the financial data from Compustat, similar to Srivastava (2014). Using the CRSP listing year merely shifts the cohort classification by a few years and does not affect the overall trends (results not tabulated).

${ }^{15}$ Fifteen firm-year observations are required to estimate industry-year regressions consistent with Roychowdhury (2006).
} 
$S G \& A$ for the youngest cohorts are approximately three times larger than for the oldest cohorts. OperatingCashFlow is negative for the youngest cohorts but positive for the oldest cohorts. Panel $\mathrm{C}$ reports that the youngest and oldest cohorts differ in their growth opportunities, measured by market-to-book ratio, and profitability, measured by return on assets and earnings-to-price ratio.

I formally test for a trend across successive cohorts (the cohort trend, $\beta_{2}$ ) by estimating the regression

$$
\text { AverageCharacteristic }=\beta_{1}+\beta_{2} \times \text { ListingVintage }+\varepsilon,
$$

where AverageCharacteristic is the pooled average of firm-year observations with the same listing vintage. $\beta_{2}$ is multiplied by -1 because listing vintage runs opposite to the succession of listing cohorts. It is multiplied by 1,000 for expositional reasons.

Panel A of Table 1 reports the cohort trend $\left(\beta_{2}\right)$ for each characteristic and its significance. $R \& D$ and $S G \& A$ show a significantly positive trend, and OperatingCashFlow and ProductionCost show a significantly negative trend. Also, older cohorts show higher profitability and lesser growth than younger cohorts. These cohort trends confirm that prior findings hold for my study sample.

\subsubsection{Reasons for expecting cohort patterns within industries}

The literature supports the idea that successive cohorts within an industry would use more intangibles in their operations for two reasons: differences in life-cycle stages and technological vintages. Industry entrants compete against incumbents by differentiating their products or by being cost leaders (Porter 1980; Miller and Friesen 1984; Prahalad and Hamel 1990). Two principal competitive strategies over the last 40 years have been to offer advanced products (Shapiro and Varian 1998; Baumol and Schramm 2010) and a one-on-one relationship with the customer (Payne and Frow 2005; Kumar and Reinartz 2012). These two strategies are referred to as product leadership and customer intimacy, respectively, and are distinguished from the strategy of operational excellence (Treacy and Wiersema 1993). For example, Tesla competed against established automobile companies by offering an all-electric, customizable vehicle. Product leadership and customer intimacy strategies require higher intangible inputs, such as $\mathrm{R} \& \mathrm{D}$, information technology, expert personnel, and customer databases than do strategies based on cost advantage (Shapiro and Varian 1998; Apte et al. 2008; Romer 1998; Baumol and Schramm 2010). Thus firms in their initial life-cycle stages and recently listed cohorts are expected to use a higher proportion of intangible inputs in their production function than do mature firms in the same industry.

Initial public offering (IPO) waves or the "hot IPO" phenomenon, the simultaneous listing of firms with similar production technologies within a broad industry category (Chemmanur and Fulghieri 1999; Benveniste et al. 2002), can also cause differences in production technologies of successive cohorts in the same industry. Such differences are evident from the IPO waves of biotechnology firms in 1990 within the broad SIC code of 28 (chemical and allied products), dot.com firms in 1998-1999 within the broad SIC code of 73 (business services), and shale oil and fracking firms in 2014 within the broad SIC code of 13 (oil and gas extraction). 


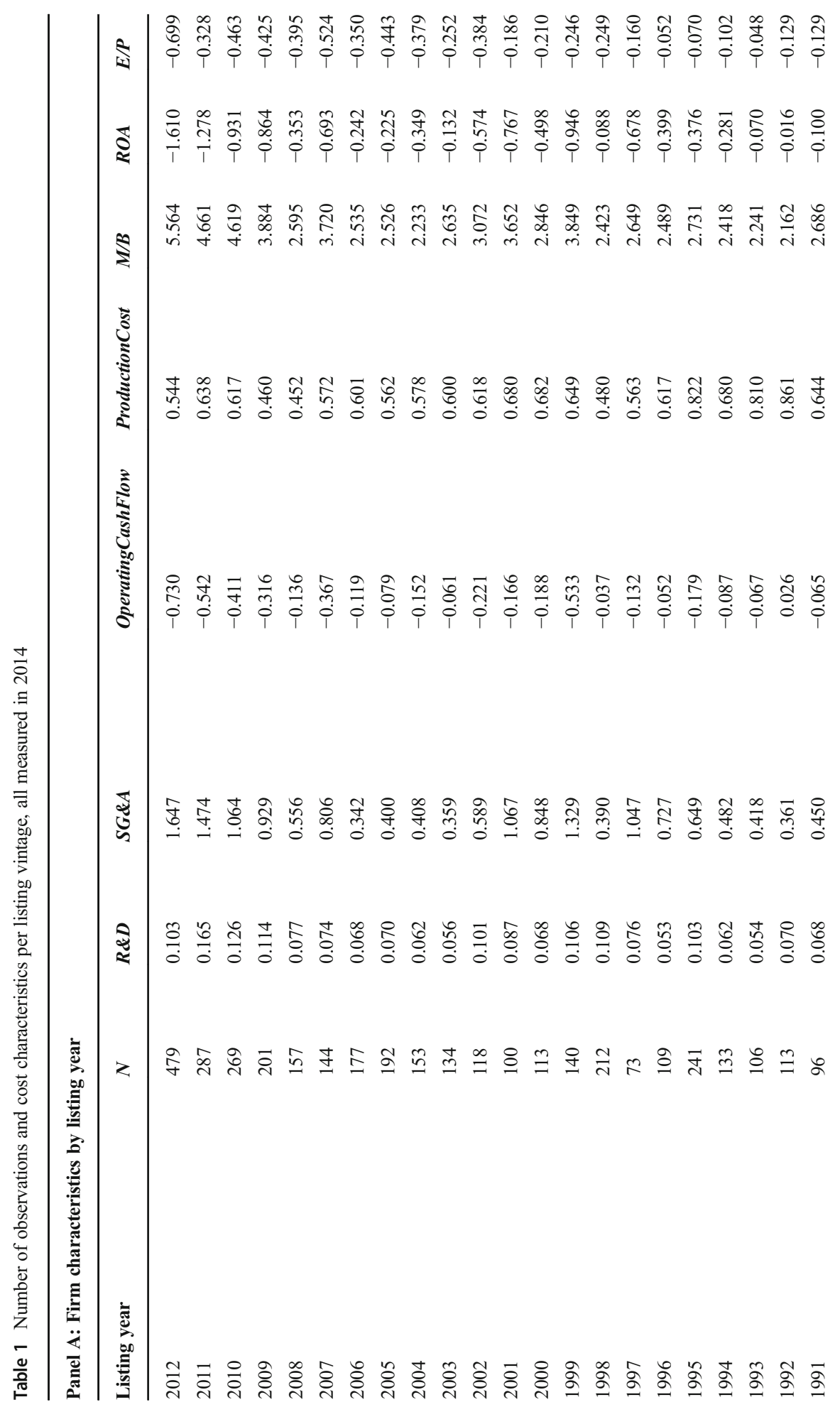




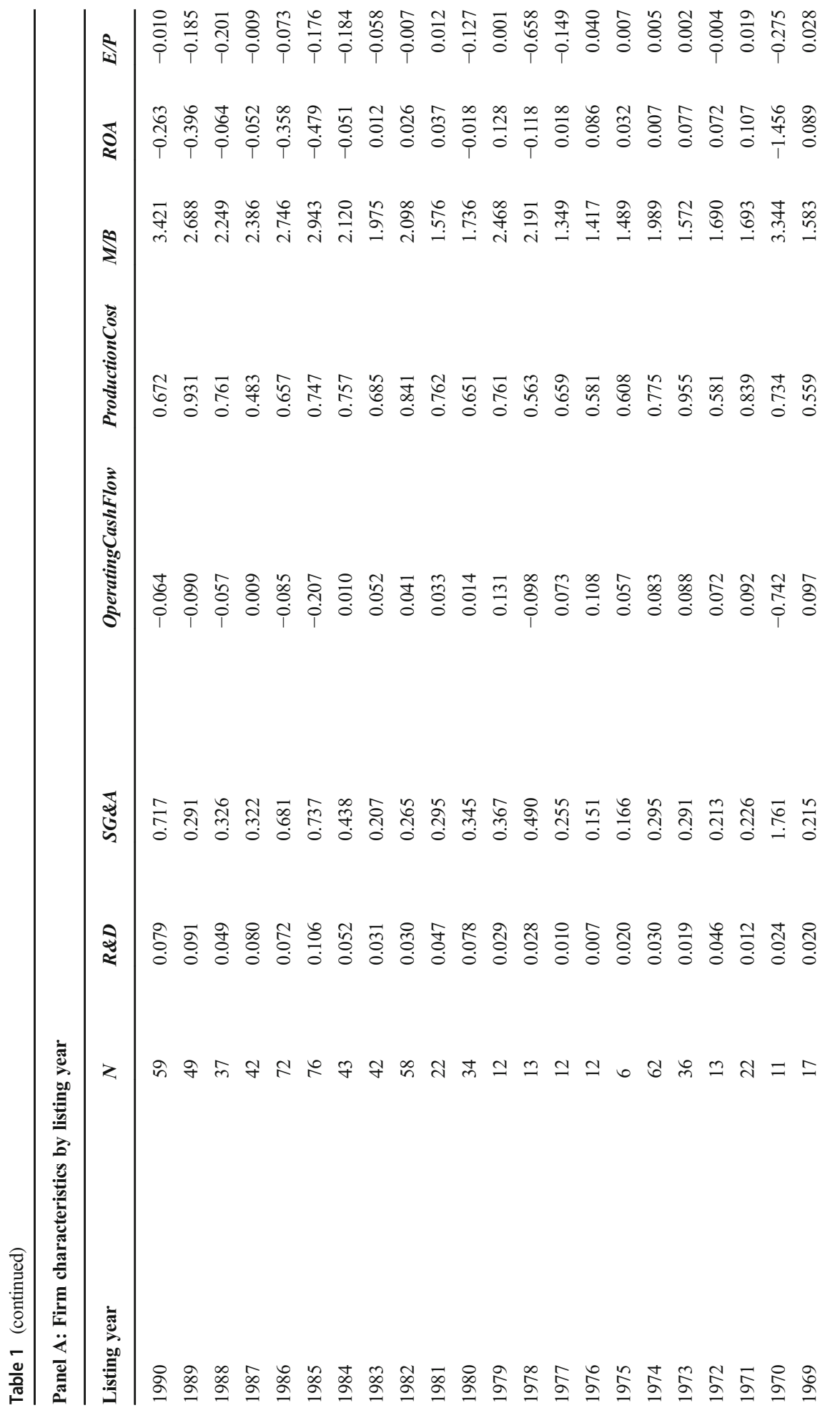




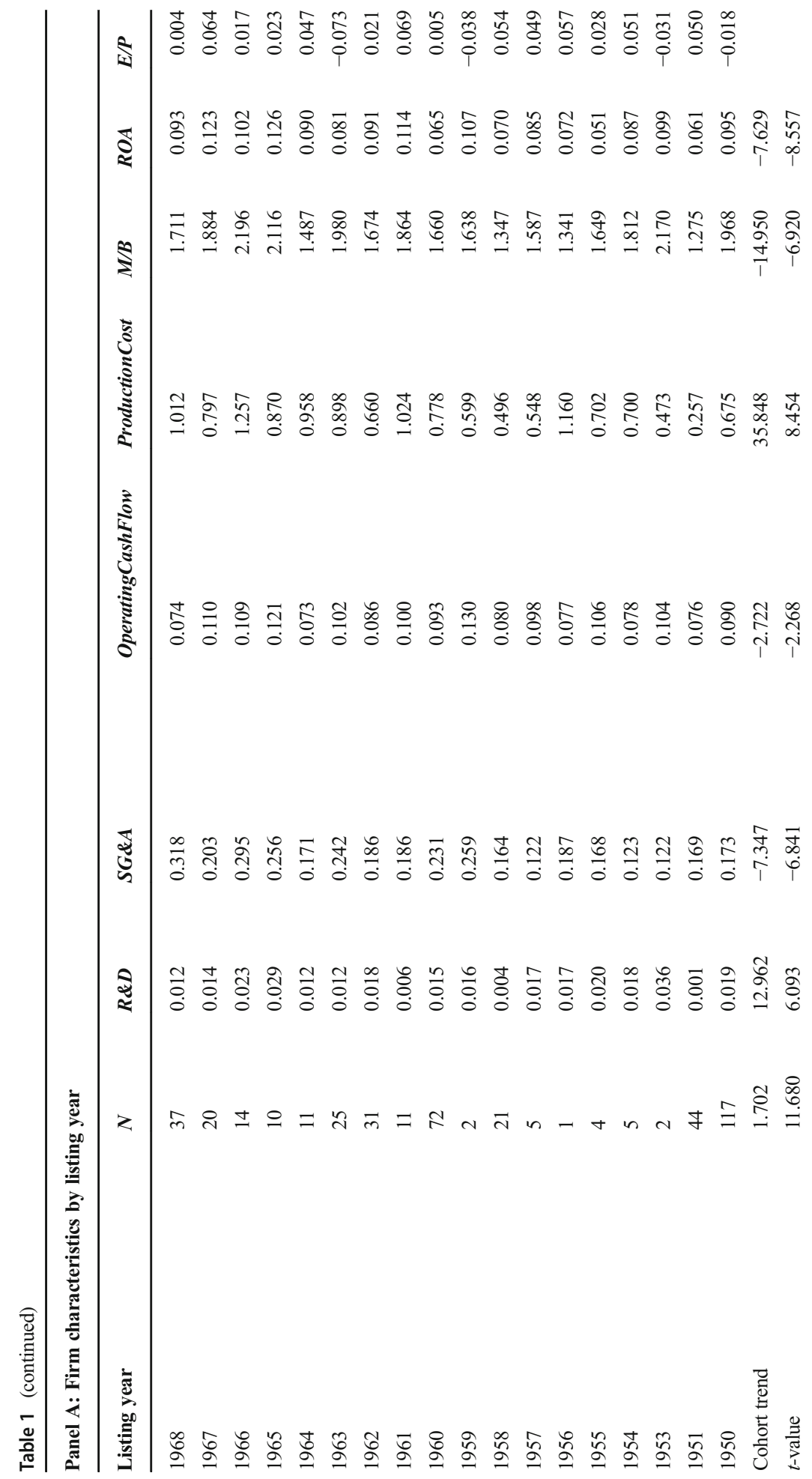




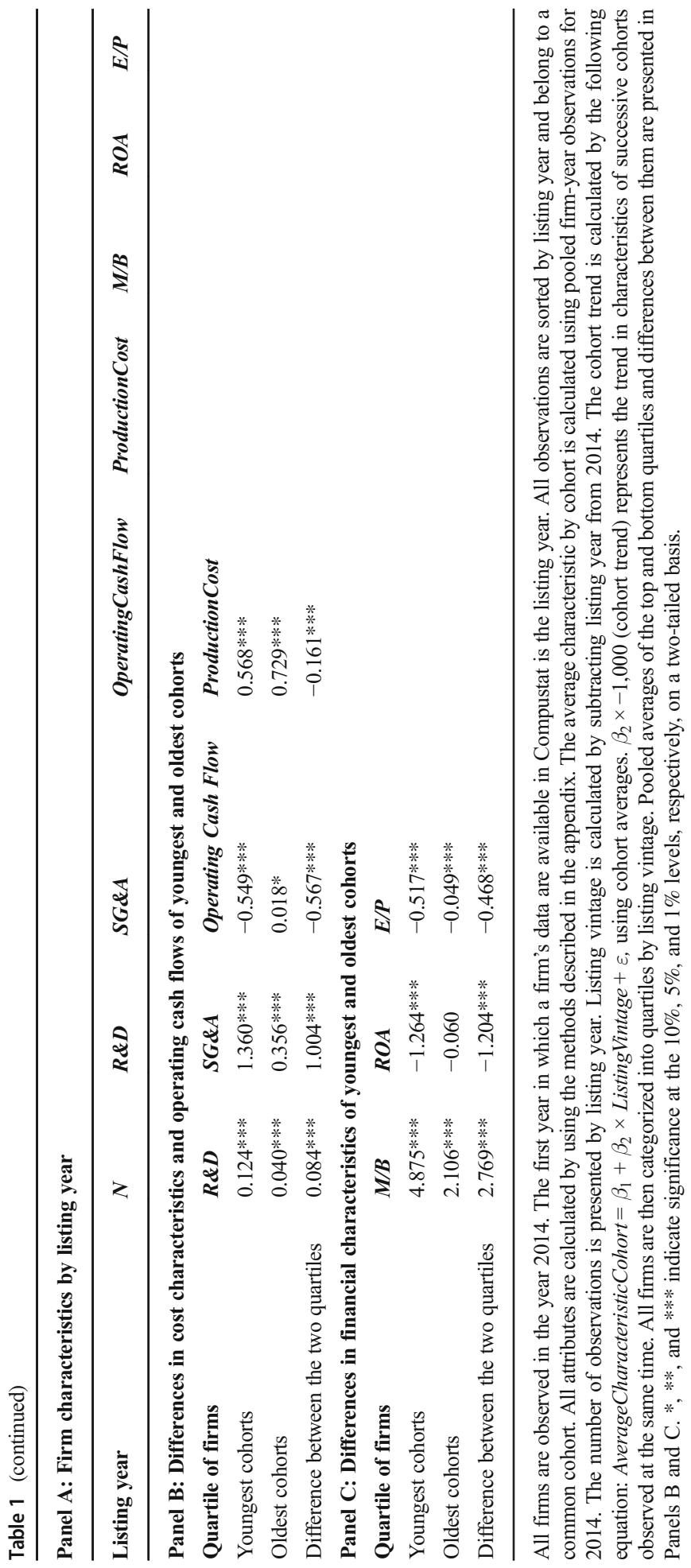


Despite productivity breakthroughs and new competitive strategies adopted by industry entrants, older cohorts might not change their business model at the same pace as entrants. ${ }^{16}$ Older firms with their successful products, established markets, and loyal customers might not realize the need for changing their ways, especially if their strategies have achieved steady profits (Christensen 1997). Even with realization, doing so might not be feasible, because it requires cannibalization of profitable products, closing of divisions, and large-scale organizational changes that impose significant disruption costs (Hambrick 1983; Yip 2004; Acs and Audretsch 1988; Chen et al. 2010; Igami 2017). As a result, firms retain their initial business model adopted based on the technological advances extant at the time of their formation (organizational imprinting hypothesis; Stinchcombe 1965). Thus business models are linked to the technological vintage of listing cohorts. Newer cohorts, which are in their formation stages, could leverage on technological advances to increasingly pursue the strategies of product leadership and customer intimacy (Shapiro and Varian 1998). The implication is that successive cohorts in a given industry would display progressively higher intangible intensity, even when observed at the same stage of their life cycle.

\subsubsection{Evidence of cohort patterns within industries}

I classify firms into four quartiles by their listing vintage in an industry, with the highest and lowest listing vintage representing the oldest and youngest cohort, respectively. For the four largest industries (metal and mining, chemical and allied products, electronic and other electric, and business services), I present the quartile averages of $R \& D, S G \& A$, OperatingCashFlow, and ProductionCost in Panels A1-D1 of Fig. 1, respectively. These graphics show significant differences in those variables between the oldest and youngest cohorts. The oldest cohorts display higher OperatingCashFlow and lower $S G \& A$ and $R \& D$. ProductionCost shows no consistent pattern.

The proposition that cohorts within an industry display systematic differences in costs and profitability is formally tested by estimating cohort trends (eq. (5)) by industry. The results are presented in Panel A of Table 2. Cohort trends are positive for $R \& D$ and $S G \& A$ and negative for OperatingCashFlow, respectively, for $67 \%, 87 \%$, and $90 \%$ of industries, each of which is significantly different from an unconditional value of $50 \%$. In addition, cohort trends for profitability and growth are negative and positive for, respectively, $92 \%$ and $85 \%$ of industries. Cohort trend for ProductionCost is negative for $51 \%$ of industries, not significantly different than $50 \%$.

Panel A also reports the average of within-industry cohort trends and their significance. These averages are significant for $R \& D$ (positive), $S G \& A$ (positive), OperatingCashFlow (negative), profitability (negative), and growth (positive).

\footnotetext{
${ }^{16}$ Christensen (1997) argues that new firms in an industry are more likely than incumbents to capitalize on technological innovations. Other studies claim that newer companies innovate more frequently, because they do not fear cannibalization of their products (Acs and Audretsch 1988; Igami 2017). Prahalad and Hamel (1990) and Brickley and Zimmerman (2010) assert that new firms obtain market share from old firms by differentiating their products. D'Aveni (1994) and Thomas and D'Aveni (2009) find that rivalries within industries have increased over time.
} 
Panel A1: $R \& D$ for the youngest and oldest cohorts for the four largest industries

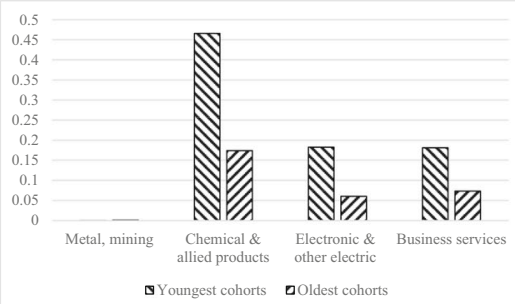

Panel B1: $S G \& A$ for the youngest and oldest cohorts for the four largest industries

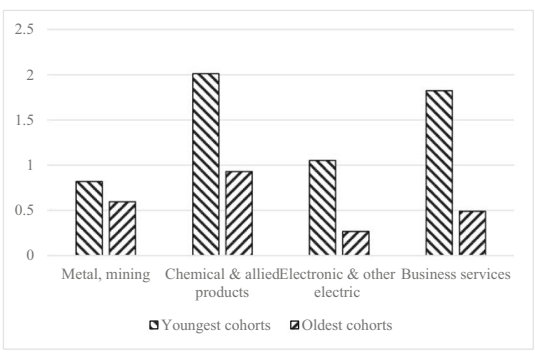

Panel C1: OperatingCashFlow for the youngest and oldest cohorts for the four largest industries

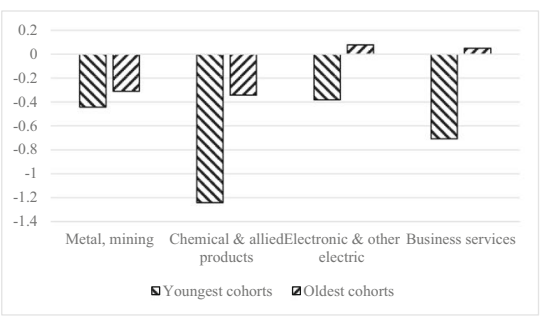

Panel D1: ProductionCost for the youngest and oldest cohorts for the four largest industries

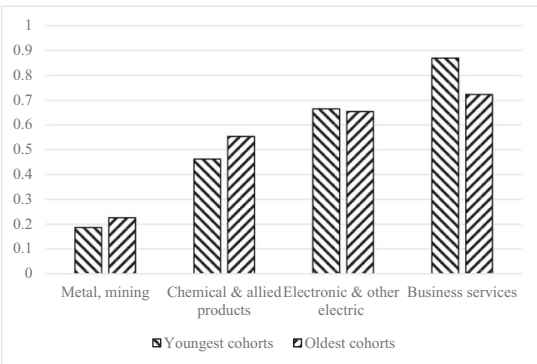

Panel A2: AbnormalR \&D for the youngest and oldest cohorts for the four largest industries

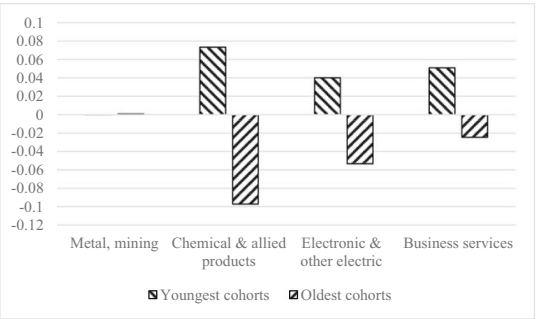

Panel B2: AbnormalSG\&A for the youngest and oldest cohorts for the four largest industries

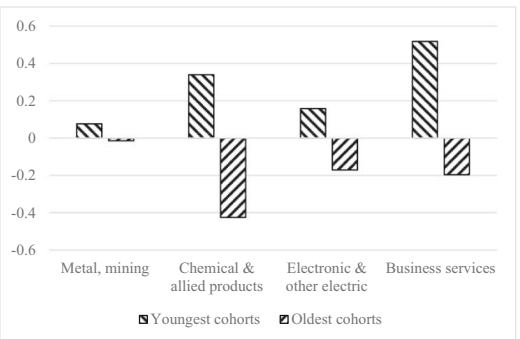

Panel C2: AbnormalOperatingCashFlow for the youngest and oldest cohorts for the four largest industries

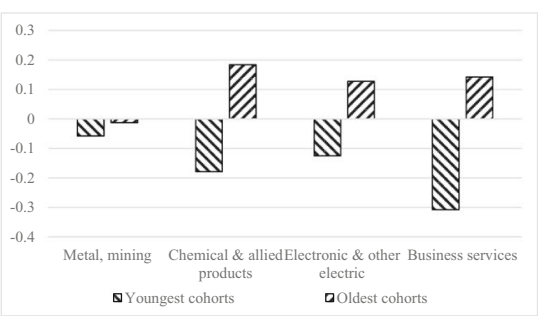

Panel D2: AbnormalProductionCost for the youngest and oldest cohorts for the four largest industries

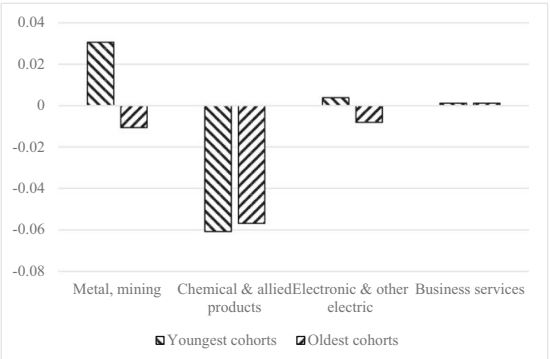

Fig. 1 Reported and abnormal values of manipulated variables for the four largest industries. All firms are observed in 2014. Industry is defined by two-digit Standard Industrial Classification code. Observations from the largest four industries are retained. Cost characteristics, operating cash flows, and their abnormal values are calculated using methods described in the appendix. The first year in which a firm's data are available in Compustat is the listing year. Listing vintage is calculated by subtracting the listing year from 2014. All observations are sorted by listing vintage and categorized into quartiles. The outermost quartiles are referred to as the youngest and oldest cohorts. Pooled averages of the youngest and oldest cohorts for the four industries are presented in Panels A1-D1 (reported values scaled by total assets) and Panels A2-D2 (abnormal values). Variable definitions are in the appendix 
ProductionCost does not display a significant trend. ${ }^{17}$ The results demonstrate that the characteristics of same-industry firms differ systematically based on listing cohorts.

\subsubsection{Cohort patterns reflect technological vintage, not just the life-cycle effect}

I conduct additional tests using a longer time series of data from 1965 to 2016, to establish that the cohort patterns are not entirely due to differences in life-cycle stages. I retain one observation per firm when its listing vintage is five years and industry-years with more than three observations. I then calculate pooled averages by industry-year based only on firms that are five years old in that year. All annual averages in an industry are presumably measured at the same life-cycle stage. I use them as the dependent variable in eq. (5) and estimate that regression by industry. Fiscal year becomes the independent variable, and $\beta_{2}(\times 1,000)$ represents cohort trends within each industry after controlling for firm life cycle. I then calculate the average trends in $R \& D, S G \& A$, ProductionCost, market-to-book ratio, and earnings-to-price ratio and present them in Panel B of Table 2. Results show that younger cohorts within industries have higher SG\&A and R\&D, lower profitability, and higher growth, even after controlling for life cycle. For example, a five-year-old chemical firm in 1970 differs significantly from a five-year-old chemical firm in 1990 in its cost mix, growth, and profitability.

Sections 3.1.1-3.1.4 show that the oldest and youngest cohorts within industries differ in their characteristics, because of dissimilarity in life-cycle stages or technological vintages. I extend prior studies that document such patterns in the overall set of listed firms to within-industry contexts (Brown and Kapadia 2006; Srivastava and Tse 2016). Many research methods in accounting and finance assume uniformity in characteristics of same-industry firms. This section shows that any model that estimates a firm's abnormal, manipulative, or suboptimal behavior by deviation from industryaverage behavior must control for differences in life cycle and technological vintage in same-industry firms.

\subsection{The assumption of revenues being the sole driver of normal costs}

The right-hand-side variables in eqs. (1)-(4) are derivatives of current or past revenue. A critical assumption in the Roychowdhury (2006) models is that current or past revenue solely determines normal costs and profits. The Roychowdhury findings also indicate that different models violate this assumption to a varying degree and thus are dissimilarly under-specified. ${ }^{18}$

\footnotetext{
${ }^{17}$ Nevertheless, manufacturing industries, such as stone, clay, and glass products, furniture and fixtures, lumber and wood products, metal and mining, paper and allied products, primary metal industries, and chemical and allied products display negative trends, indicating that successive cohorts rely less on tangible inputs. Thus a researcher could obtain different results using the production cost model by examining manufacturing industries compared with the entire firm population.

18 The correlation of SG\&A with current revenues (0.39) is significantly lower than for production cost $(0.95)$ (Roychowdhury 2006, p. 350). The correlation of operating cash flow with revenues is even smaller (0.11). As a result, the adjusted R-squared of the SG\&A model is just $38 \%$, significantly lower than the $89 \%$ R-squared of the production cost model (Roychowdhury 2006, p. 349).
} 


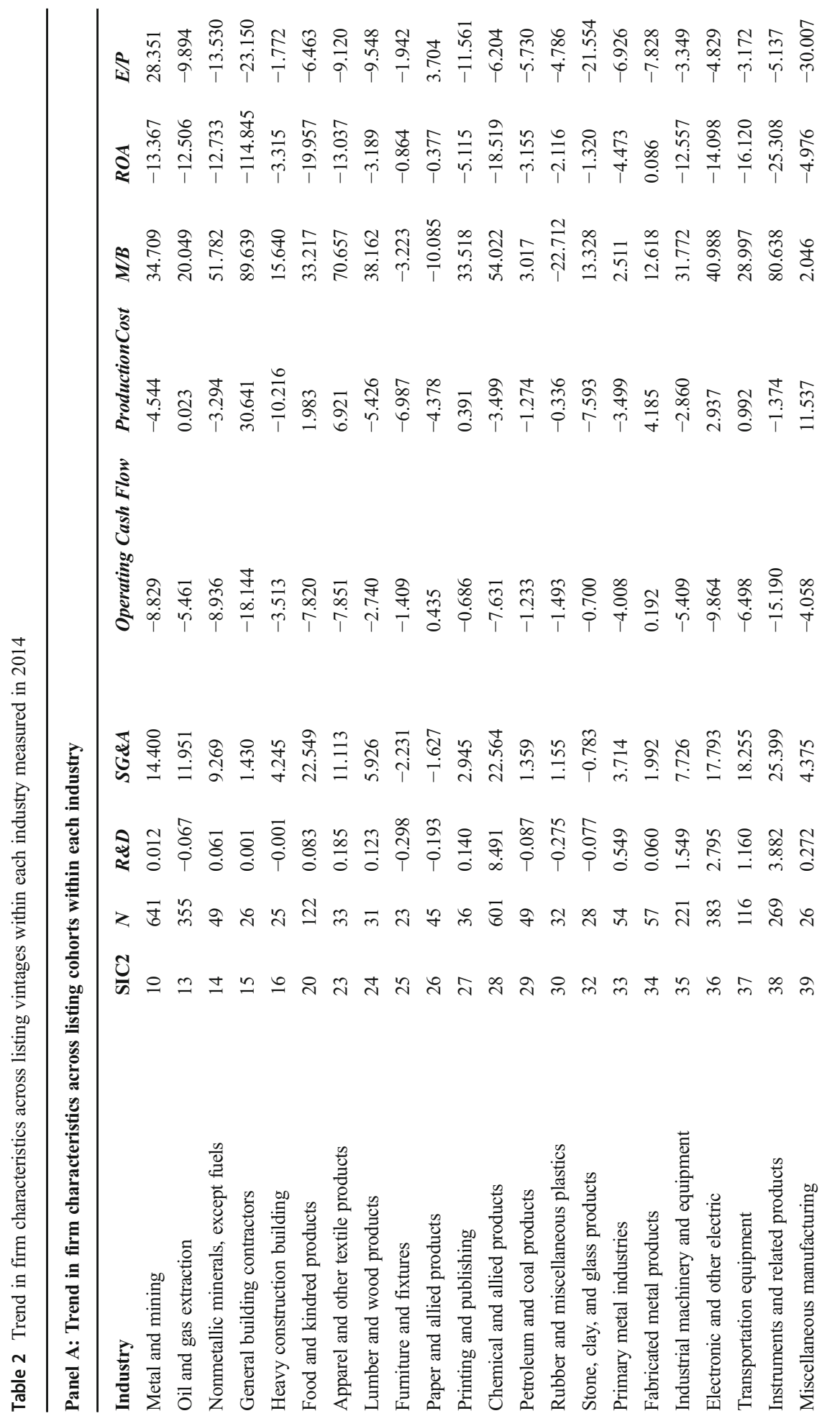




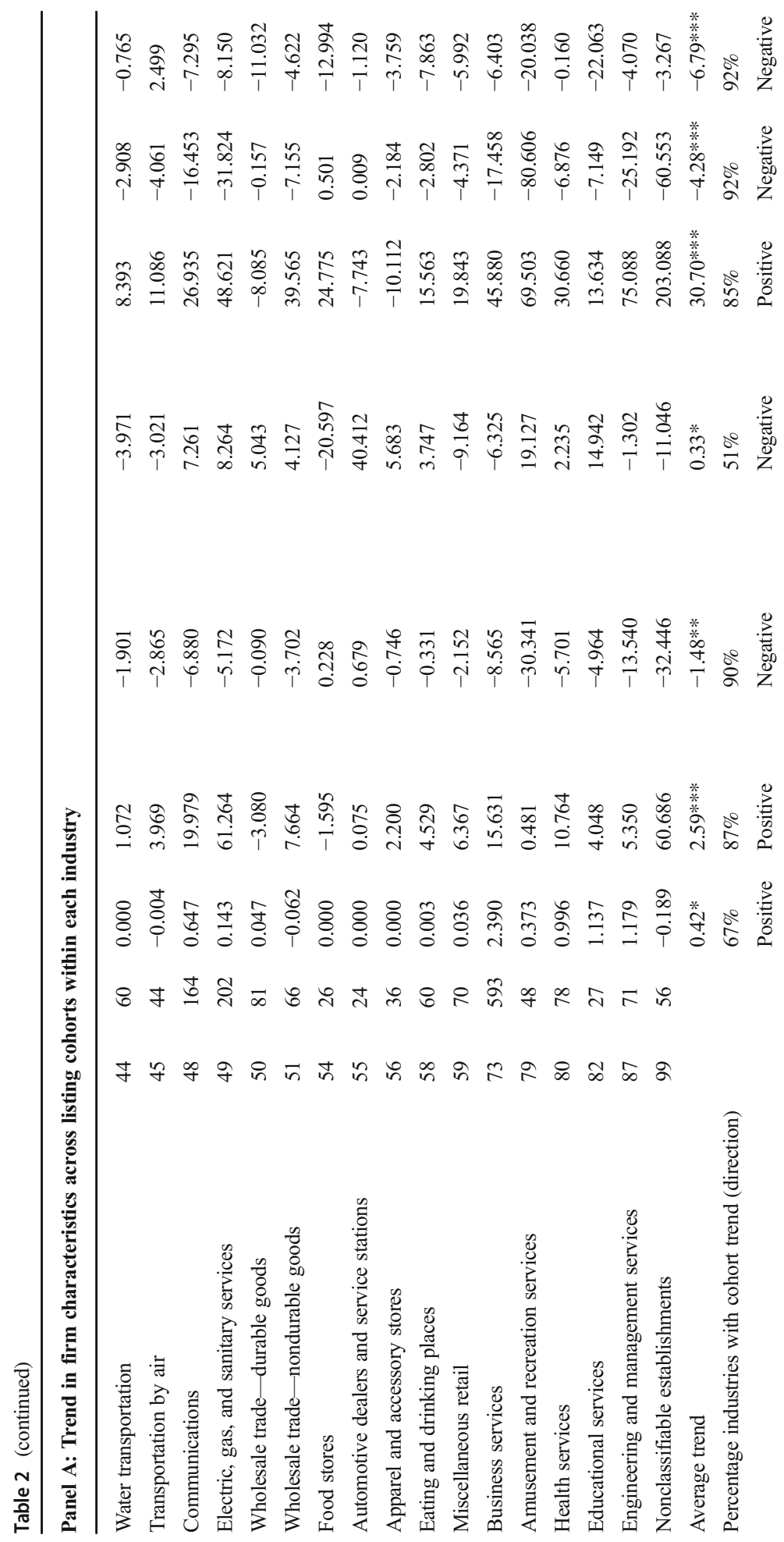




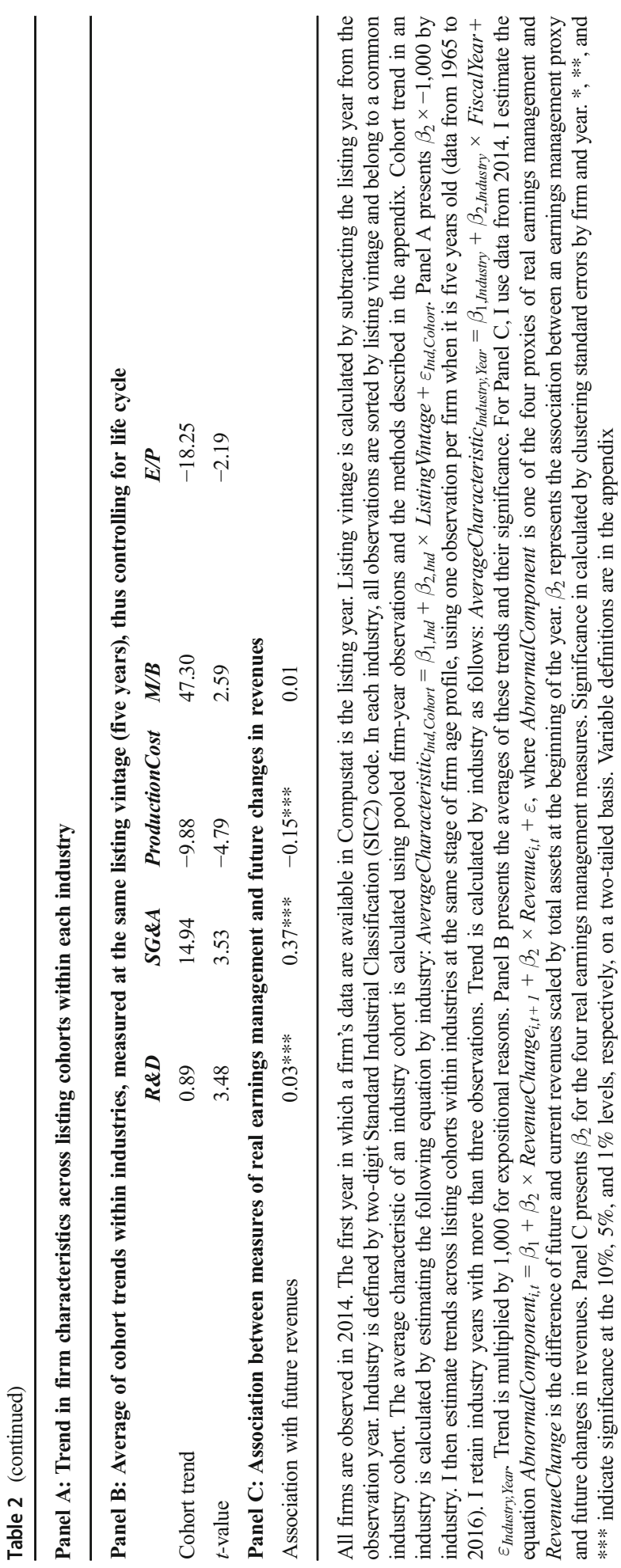


COGS, the main component of production costs, includes direct manufacturing costs and the expensed portion of capitalized manufacturing costs, both of which are typically traced to revenues. So the production cost model could be well specified. SG\&A includes outlays on innovation, strategy, market research, customer and social relationships, computerized data and software, brands, and human capital. These outlays improve organizational knowledge and competencies (Eisfeldt and Papanikolaou 2013), which are essential elements for creating advantage vis-à-vis competitors and earning long-term profits (Wernerfelt 1984; Peteraf 1993; Lev and Sougiannis 1996; Dosi et al. 2000; Banker et al. 2011; Eisfeldt and Papanikolaou 2013; Enache and Srivastava 2018). Consistent with this idea, Banker et al. (2011) find that SG\&A expenses are associated with improvement in up to three-year-forward operating profits. Sougiannis (1994) and Lev and Sougiannis (1996) show that R\&D is associated with increases in the next five years' earnings.

Discretionary cost models therefore must be under-specified in that they might not include a key determinant of firms' optimal decisions, that is, plans for future market share, revenues, or profits. I test this proposition by examining whether the residuals from discretionary cost models are associated with changes in future revenues. A positive association between abnormal discretionary costs and future revenue growth would show that discretionary costs include investments in expectation of future benefits.

I estimate the equation

AbnormalComponenti, $\mathrm{t}=\beta_{1}+\beta_{2} \times$ RevenueChangei, $\mathrm{t}+1+\beta 3 \times$ Revenuei, $\mathrm{t}$

$$
+\varepsilon
$$

where AbnormalComponent is one of the four proxies of real earnings management and RevenueChange is the difference between the next year's and current year's revenues. All variables are scaled by total assets at the beginning of the year. The coefficient of interest is $\beta_{2}$, which is presented in Panel $\mathrm{C}$ of Table 2 . The abnormal components of $R \& D$ and $S G \& A$ are positively associated with future revenue growth ( $p$ value $<0.01$ ). The abnormal OperatingCashFlow bears significant negative association. ${ }^{19}$ The abnormal ProductionCost is not significantly associated with future revenue growth. Discretionary cost models thus measure real earnings management with errors, representing within-industry differences in intangible investments made in expectation of future revenues.

In sum, Section 3 shows that successive cohorts within an industry differ systematically in their competitive strategy and profitability. Furthermore, the current REM models are under-specified in that they do not control for competitive strategy or underlying profitability.

\footnotetext{
$\overline{{ }^{19} \text { See Bernard and Stober (1989) }}$ for possible reasons for this negative relation.
} 


\section{Differences in proxies of real earnings management by listing cohorts}

Measurement errors in discretionary cost models would appear in regression residuals. Younger cohorts, with their larger discretionary costs and in conjunction with underspecified models, would show higher residuals than the older cohorts. But regression residuals must add up to zero. So the oldest cohorts would show negative residuals, and the youngest cohorts would show positive residuals. I test this proposition by classifying all firms into quartiles by their listing vintage within each industry. For the four largest industries (metal and mining, chemical and allied products, electronic and other electric, and business services), I present the quartile averages of abnormal components of $R \& D, S G \& A$, OperatingCashFlow, and ProductionCost in Panels A2-D2 of Fig. 1, respectively. The total value for each variable for the same cohort is presented alongside in Panels A1-D1 for easy comparison. In three of the four industries, the abnormal values of $R \& D$ and $S G \& A$ are negative for the oldest cohorts and positive for the youngest ones. The abnormal values of OperatingCashFlow are positive for the oldest cohorts and negative for the youngest ones. These patterns give the appearance of significant real earnings management by the oldest cohorts. No consistent evidence on real earnings management for the oldest cohorts is obtained with abnormal production costs.

I then calculate the average values of abnormal components for the youngest and oldest cohorts for the pooled sample. Panel A of Table 3 shows that the abnormal values for $R \& D, S G \& A$, OperatingCashFlow, and ProductionCost are, respectively, $0.027,0.204,-0.119$, and 0.007 for the youngest cohorts and $-0.026,-0.144,0.075$, and -0.021 for the oldest cohorts. All of these values are significant (except abnormal production cost for the youngest cohorts). All of the differences between the youngest and the oldest cohorts are also significant.

Two patterns are noteworthy. First, the magnitude of ratios of abnormal to total value for $R \& D, S G \& A$, and OperatingCashFlow is much larger than that for ProductionCost. (Total values are presented in Panel B of Table 1.) The magnitude of ratios for the oldest cohorts is $65 \%(-0.026 / 0.040)$ for $R \& D, 40 \%(-0.144 / 0.356)$ for $S G \& A$, and $416 \%(0.075 / 0.018)$ for OperatingCashFlow but only $3 \%(0.021 / 0.729)$ for ProductionCost. Thus discretionary cost and cash flow models produce relatively large residuals. Second, those residuals carry statistically significant values for the oldest and youngest cohorts but in opposite directions. (The residuals for the middle two cohorts are relatively small.) A researcher would interpret the abnormal values for the oldest cohorts as undercutting of discretionary costs. The youngest cohorts do not display real earnings management using any measure. They would appear to overspend on intangibles, as if exacerbating their already low profits.

I consider 0.05 as a threshold for interpreting significant earnings management, consistent with the anecdotal evidence that $5 \%$ of total assets is considered a material amount. I use a threshold of 0.01 for $R \& D$, because it is a much smaller number than the other three variables. I then estimate the percentage of firms showing earnings management in randomly drawn samples from the oldest and the newest cohorts.

I draw 100 random samples of 100 observations each from the top and bottom quartiles and estimate the likelihood of obtaining materially significant values for the four abnormal components in the direction consistent with real earnings management. I 
calculate percentage of observations with AbnormalR\&D less than -0.01 , AbnormalSG\&A less than -0.05, and AbnormalOperatingCashFlow and AbnormalProductionCost greater than 0.05. Panel B of Table 3 presents these likelihoods. For the oldest cohorts, the likelihood of detecting large real earnings management based on R\&D, SG\&A, operating cash flow, and production cost is $92 \%, 94 \%$, $81 \%$, and $6 \%$, respectively. For the youngest cohorts, the same likelihoods are $0 \%, 1 \%$, $0 \%$, and $6 \%$, respectively. Stated differently, randomly drawn samples from the oldest cohorts almost always appear to cut discretionary costs but do not appear to manipulate production costs. The same is not true for the youngest cohorts. This phenomenon explains a typical finding of real earnings management studies relying on the Roychowdhury (2006) models that firms with low growth, large size, and high profitability cut discretionary costs, because these are more likely to be the characteristics of older cohorts than younger cohorts. Furthermore, studies find significant results with $S G \& A, R \& D$, and OperatingCashFlow but rarely with ProductionCost. ${ }^{20}$

The findings of this section are consistent with the idea that the inferences of real earnings management in the literature could represent violations of two assumptions underlying the REM estimation models: (1) all firms in an industry have the same cost and cash flow patterns when not managing earnings; (2) sales revenue is the sole driver of costs and profitability in the normal course of business.

\section{Oldest cohorts' characteristics: real earnings management or competitive strategy}

Oldest cohorts give the appearance of perpetually undercutting discretionary costs, which, I argue, reflects their competitive strategies. Yet these patterns could represent higher earnings management by the oldest cohorts. I conduct additional tests to determine whether the cohort patterns in proxies for real earnings management reflect competitive strategies or earnings management, on average.

\subsection{Persistence in the proxies of real earnings management}

A premise underlying the real earnings management literature is that the practice represents a temporary deviation from the firm's routine business to meet a shortterm financial reporting target. That temporary conduct should reverse in the next period; otherwise, the firm's competitive ability will be impaired. For example, to maintain a level of innovation, firms should increase R\&D after an opportunistic cut. In that case, the abnormal components of successive periods should be negatively

\footnotetext{
${ }^{20}$ Cohen et al. (2008, Figure 4, p. 774) find that the magnitude of abnormal discretionary costs is three to five times higher than the magnitude of abnormal production cost. McInnis and Collins (2011, pp. 231, 232) find a significant difference in the manipulation of discretionary costs by treatment and control firms but no such difference in the manipulation of production volume. Kim and Park (2014, p. 388) find a significant (no significant) relation between auditor resignation of suspect clients and abnormal discretionary costs (abnormal production expenses). Chan et al. (2015, p. 157) find a significant (no significant) relation between the adoption of clawback provisions and abnormal discretionary costs (abnormal production expenses).
} 


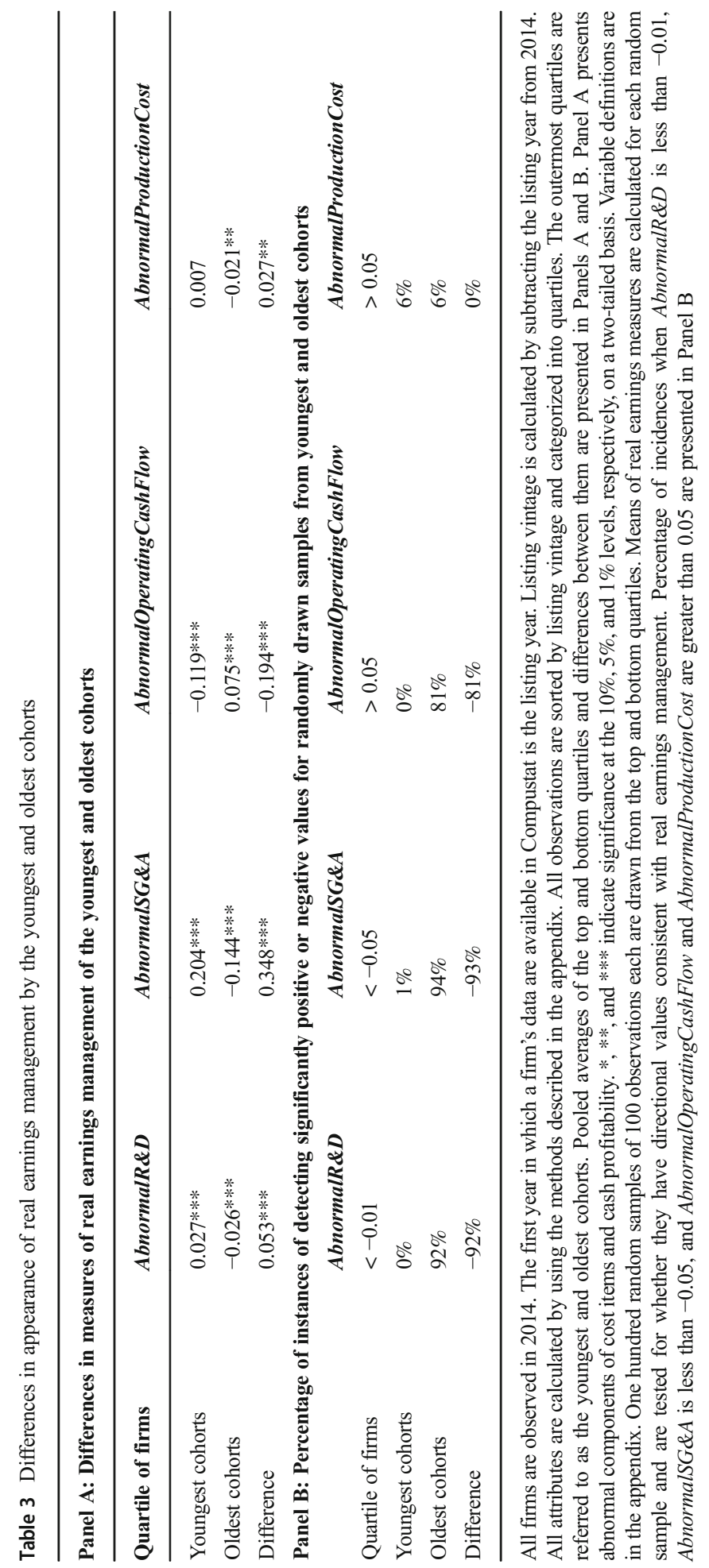


correlated. ${ }^{21}$ If an abnormal component represents a firm's relatively stable competitive strategy (Porter 1980), then it would display positive serial correlation.

Panel A of Table 4 presents results of serial correlation tests. ${ }^{22}$ I find high persistence in the abnormal components of R\&D, SG\&A, operating cash flow, and production cost (Siriviriyakul 2015). The coefficient on lagged values is $0.67,0.67,0.51$, and 0.58 , respectively, all significant at $p$-values $<0.01$. These metrics are large enough to signify a stable time series. These patterns more likely represent a firm's long-term strategy than a short-term tactic.

\subsection{Incentives for earnings management}

A firm must have a motive for REM, because deviating from an optimal operating policy can impose long-term costs. Temporarily misleading external capital providers about performance is arguably the strongest motive for earnings management (Dechow and Skinner 2000). Table 2 shows that the oldest cohorts display low growth but high profitability, indicative of large cash surplus and low need for external capital infusion. Panel B of Table 4 shows that the value of secondary equity offering (Compustat SSTK / total assets at the beginning of the year) for the youngest cohorts is 0.499 , which is several times higher than the value for the oldest cohorts, 0.074 . These results indicate that the oldest cohorts have the lowest incentives to mislead external capital providers.

Yet, relative to the youngest cohorts, the oldest cohorts with their greater institutional holdings and analyst following might face higher pressure to meet financial targets. Panel $\mathrm{C}$ of Table 4 shows that the frequency of reporting small profits and small positive changes in profits is higher for the oldest cohorts. However, a very similar trend is observed for just missing the earnings targets. These patterns could represent the fact that the earnings of the oldest cohorts are more stable and occur in a narrower range than for the youngest cohorts, which increases the likelihood of observing just missing or just beating earnings targets. (Studies show that the older cohorts have lower earnings volatility than younger cohorts.) More important, no evidence emerges that the oldest cohorts have higher incentives for managing earnings or that they manage earnings more frequently than the youngest cohorts.

\subsection{Normal costs}

Prolonged cutting of necessary business expenses, if done merely to manage earnings, should harm a firm's long-term profitability. For example, a continual pattern of suboptimal investments in R\&D, training, or advertising must lower a firm's competitive advantage. So the oldest cohorts, which based on current models appear to perpetually cut necessary expenditures, must have the lowest profitability. However, they continue to earn the largest profits in the industry year after year. Thus spending the lowest amounts on intangibles could be consistent with their normal ways of doing business. Panel D of Table 4 supports this idea. It shows that the normal components of $R \& D$ and $S G \& A$ for the oldest cohorts are lower than those for the youngest cohorts.

\footnotetext{
${ }^{21}$ Discretionary accruals display this pattern (Baber et al. 2011).

22 Persistence $\left(\gamma_{2}\right)$ is calculated on a firm-year basis by estimating Characteristic $_{i, t}=\gamma_{1}+$ $\gamma_{2} \times$ Characteristic $_{i, t-1}+\varepsilon_{i, t}$.
} 


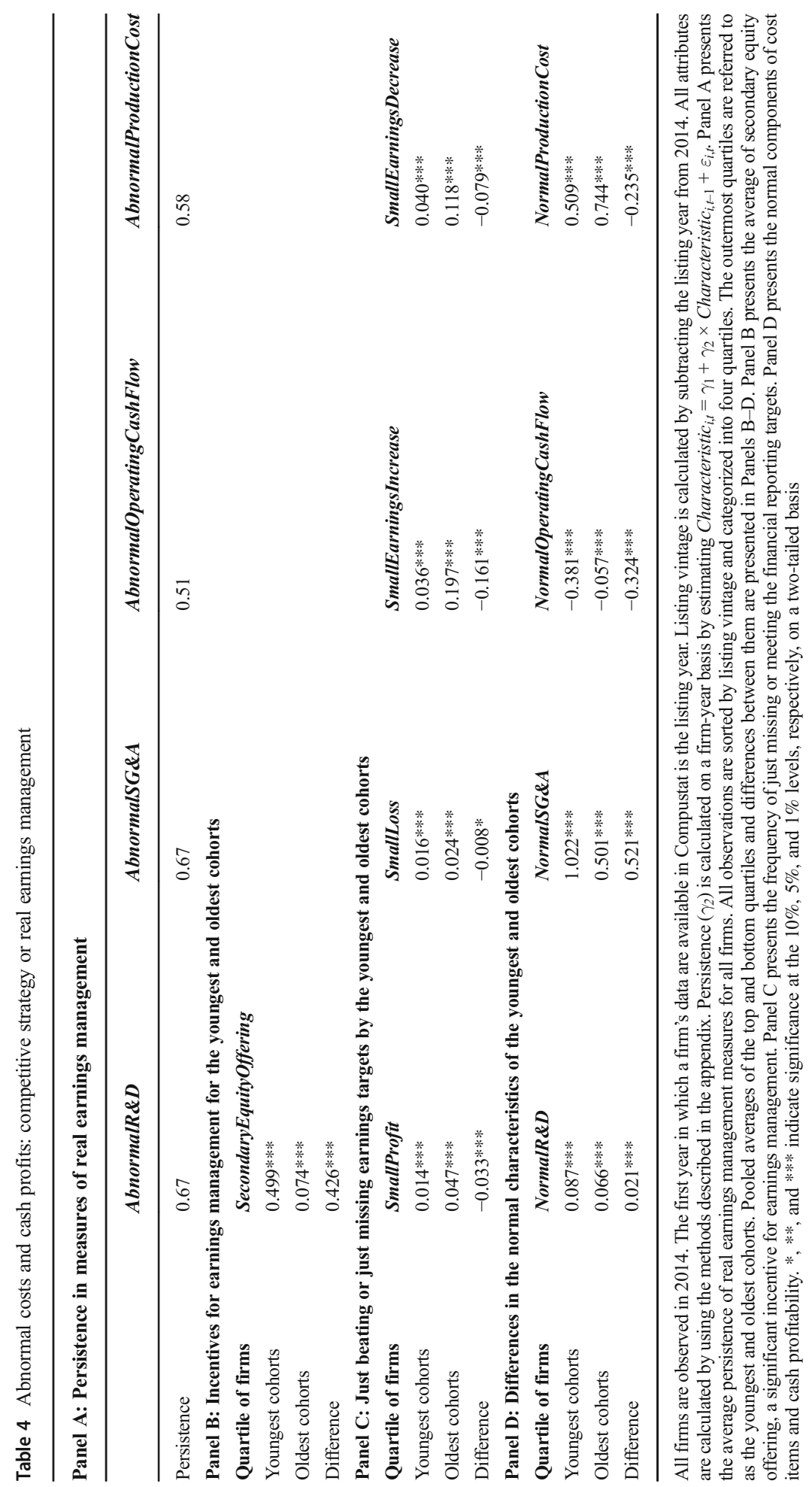




\subsection{Discussion}

Results of Sections 5.1-5.3 indicate that the lower intangible investments by the oldest cohorts likely reflect their business strategies. Only the survivors from the oldest cohorts are observed in the measurement year. (The median age of the oldest cohorts is 40.8 years, compared with 3.1 years for the youngest cohorts - not tabulated.) Firms that have survived for 41 years must have achieved economies of scale, pursued more successful strategies, created better products and brands, or established more stable markets, loyal customers, or network externalities than the other firms. These unique advantages must now enable them to earn profits without having to make as large intangible investments as the other firms (Amit and Schoemaker 1993; Agarwal and Gort 2002). So the oldest cohorts can now pursue the strategy of operational excellence, to protect or gradually enhance their profits (Treacy and Wiersema 1993). Entrants, in contrast, must spend higher amounts on strategy, R\&D, advertising, brand development, or customer acquisition, to disturb industry equilibria and build unique competencies. These differences in business strategies, combined with the under-specifications of estimation models, could lead to the appearance that the oldest cohorts undercut discretionary costs.

I therefore conclude that the current models cannot distinguish between the firm's distinct competitive strategy and its manipulations, both of which require different levels of costs than industry peers. Therefore the construct validity of the discretionary cost-based proxy of real earnings management is doubtful; that is, it may not represent what it purports to (Cook and Campbell 1979).

\section{Improvements in measurement models}

Measurement errors in empirical proxies, if randomly distributed, should merely reduce the power but not bias the results of the tests of the hypotheses. However, measurement errors in three of the four real earnings management proxies are not randomly distributed. They display cohort patterns and are manifestations of competitive strategy. This systematic measurement error could cause spurious correlations in any hypothesis test involving a firm characteristic that is driven by firm's competitive strategy. Researchers can therefore document spurious correlations between earnings management and that strategy-driven characteristic.

I propose a sequence of corrective steps to mitigate these possible errors. First, I include the widely accepted proxies for a firm's opportunity set of size, past profitability, and growth in the first-stage model (Gunny 2010). Second, I include future revenues in the model, because firms spend on intangibles not only to produce current revenues but also to secure future benefits. Third, I control for the firm's own past expenses to identify deviations from the firm's behavior in prior years (Gunny 2010). Hence I estimate eqs. (1)-(4) with the inclusion of five new variables. For example, eq. (1) is recalculated by

$$
\begin{aligned}
& \text { ProductionCost }_{i, t}=\beta_{1}+\beta_{2} \times \frac{1}{\text { Total Assets }_{i, t-1}}+\beta_{3} \times \frac{\text { Sales }_{i, t}}{\text { Total Assets }_{i, t-1}}+\beta_{4} \times \frac{\Delta \text { Sales }_{i, t}}{\text { Total Assets }_{i, t-1}}+\beta_{5} \times \frac{\Delta \text { Sales }_{i, t-1}}{\text { Total Assets }_{i, t-1}} \\
& +\beta_{6} \times \text { LogMarketValuei, } t+\beta_{7} \times \text { LagROAi, } t+\beta_{8} \times M / B i, t+\beta_{9} \times \frac{\text { Sales }_{i, t+1}}{\text { Total Assets }_{i, t-1}}+\beta_{10} \times \text { ProductionCost }_{i, t-1}+\epsilon_{i, t}
\end{aligned}
$$


The new variables are in the second line of eq. (7). Even if successfully applied, these three sets of controls cannot correct for a firm's optimal business response to an external shock or opportunity in the given year, which would appear as a deviation from the firm's own past behavior. This factor can be controlled by a cohort adjustment motivated by the assumption that firms in similar life-cycle stage and with similar technology vintage experience similar economic shocks and have similar optimal response. A firm's abnormal behavior is thus estimated by subtracting the activity of a same-cohort firm having similar size from the activity of the given firm to obtain a cohort-adjusted measure. $^{23}$

I next investigate whether my sequence of steps mitigates the three characteristics that a valid earnings management measure should not display: (1) persistence, (2) greater earnings management by older cohorts, and (3) more frequent rejection of the null hypothesis of no real earnings management measures for randomly drawn samples from older cohorts. The results are presented by sequentially applying size, past profitability, and growth; future revenues; past expenditures; and cohort adjustment.

Results for persistence are presented in Panel A of Table 5. Persistence dramatically declines from 0.67 to $0.11,0.67$ to $0.08,0.51$ to 0.06 , and 0.58 to 0.10 , respectively, for AbnormalR\&D, AbnormalSG\&A, AbnormalOperatingCashFlow, and AbnormalProductionCost, after I apply the four corrective steps. This panel also shows how different steps dissimilarly reduce persistence. Size, past profitability, and growth most significantly mitigate persistence for AbnormalSG\&A (arguably by controlling for firm's opportunity set) and AbnormalOperatingCashFlow (arguably by controlling for underlying profitability). Inclusion of one-year-forward revenues further reduces persistence for AbnormalSG\&A, because SG\&A produces benefits in the next year. It makes no difference for the production cost model, because COGS bears little correlation with future revenues. Controlling for the past values, perhaps mechanically, reduces persistence for all variables. But cohort adjustment also significantly reduces persistence.

I next examine the effect of the corrective steps on cohort patterns. In addition to presenting the values for the oldest and youngest cohorts and their difference after each step, I present the percentage reduction in the oldest cohort-youngest cohort difference. As in persistence tests, the controls for size, past profitability, and growth most significantly mitigate the cohort difference for SG\&A and operating cash flow-based proxies. This step also mitigates the difference for AbnormalR \&D by almost $50 \%$. By the third step, the differences are significantly reduced by $81 \%, 99 \%$, and $82 \%$ for the abnormal components of $R \& D, S G \& A$, and OperatingCashFlow, respectively. Finally, cohort adjustment mechanically reduces the difference in all variables, making it statistically insignificant.

Another noteworthy result is the decline in the absolute value of the abnormal components with each step. For example, for the oldest cohorts, the absolute value of Abnormal $S G \& A$ reduces from 0.144 to 0.049 , with the application of size, past profitability, and growth, and further to 0.002 , with control for future revenues and lagged values - a total reduction of $98.7 \%$. These results indicate that real earnings

\footnotetext{
${ }^{23}$ Cohort adjustment can also control for technological vintage and IPO waves. These two phenomena cannot be controlled in a panel data regression by just using firm age, which would treat all same-age observations appearing in different years as equal.
} 
management, as measured by the residuals from Roychowdhury (2006) models, could be overstated (Ball 2013).

I next examine the frequency of rejecting the null hypothesis of no earnings management for the oldest cohorts. As in Table 4 tests, I use the absolute value of 0.01 as the threshold for AbnormalR \&D and 0.05 as the threshold for Abnormal $S G \& A$, AbnormalOperatingCashFlow, and AbnormalProductionCost. Panel C shows that the frequency of rejection of the null hypothesis declines with each sequential step. The difference between the oldest and youngest cohorts disappears and flips its sign after the fourth step is implemented. Results after the application of corrective steps indicate that the youngest cohorts manage earnings more than the oldest cohorts, a pattern consistent with their capital market incentives.

I next assume that any firm displaying earnings management in a randomly selected sample represents a false negative. From a randomly selected sample of $10 \%$ of firms, I call observations with AbnormalR\&D less than -0.01 , AbnormalSG\&A less than -0.05 , and AbnormalOperatingCashFlow and AbnormalProductionCost greater than 0.05 as false negatives. I subtract the average of false negatives for each revised measure from the average for the original measure and call the difference the percentage reduction in false negatives. For the same random $10 \%$ firm sample, I induce real earnings management. That is, I subtract 0.01 from $R \& D$ and 0.05 from $S G \& A$ and add 0.05 to OperatingCashFlow and ProductionCost. I then calculate real earnings management proxies, using the original and the revised methods. I calculate a ratio of average number of firms showing abnormal values beyond the induced levels, for induced versus uninduced cases. I reason that this ratio represents the model's ability to identify true positives. I call it the true positive ratio. I subtract that ratio for the original measure from that for each revised measure and call the difference the percentage improvement in true positives.

I find that my proposed methods mitigate false negatives and improve true positives for all four proxies. The percentage reduction in false negatives for AbnormalR\&D, AbnormalSG\&A, AbnormalOperatingCashFlow, and AbnormalProductionCost, after implementing the proposed four steps, is $54.94 \%, 43.72 \%, 47.35 \%$, and $40.16 \%$, respectively. The percentage improvement in identification of true positives is $69.58 \%, 17.20 \%, 23.10 \%$, and $103.65 \%$, respectively.

I demonstrate the application of the sequential-correction method to Kim and Park (2014), who examine real earnings management for firms that change their auditors. ${ }^{24}$ I replicate their Table 4 using data from Audit Analytics. (They supplement those data with hand-collection.) Their Table 4 shows significant differences between real earnings management proxies for firms with auditor resignations and for firms with continuing auditors. Similar to their results, my Table 6 shows significant differences between the two groups in the abnormal components of operating cost and SG\&A but not for production cost.

I then apply my sequence of steps and find two significant differences from Kim and Park (2014). First, the absolute values of real earnings management proxies decline with each sequential step, indicating that the proxies estimated after controlling for competitive strategy are not as large as previously observed. The implication is that the existence of real earnings management for both groups is overestimated. Second, the

$\overline{{ }^{24} \mathrm{I} \text { thank an anonymous reviewer }}$ for this suggestion. 


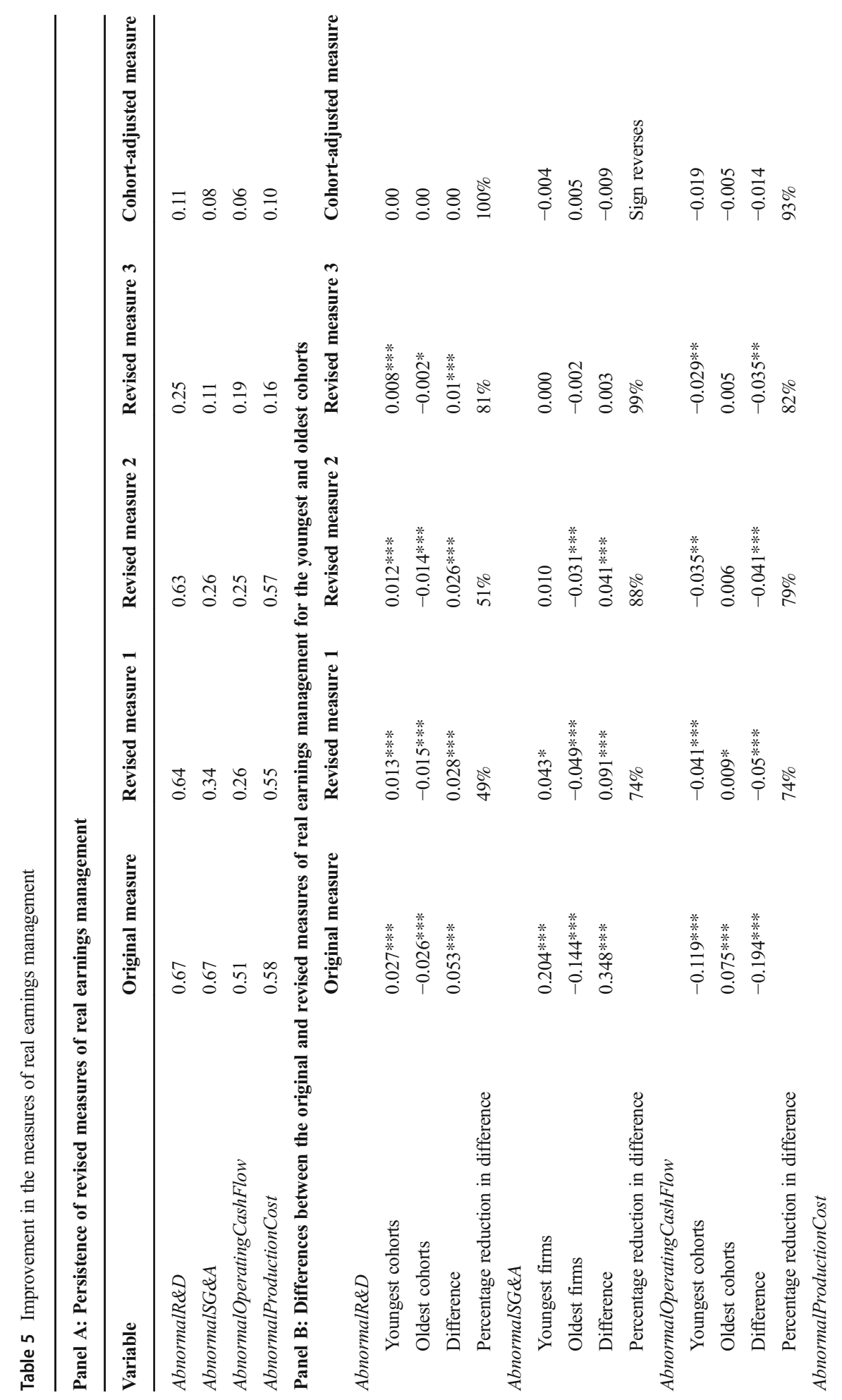




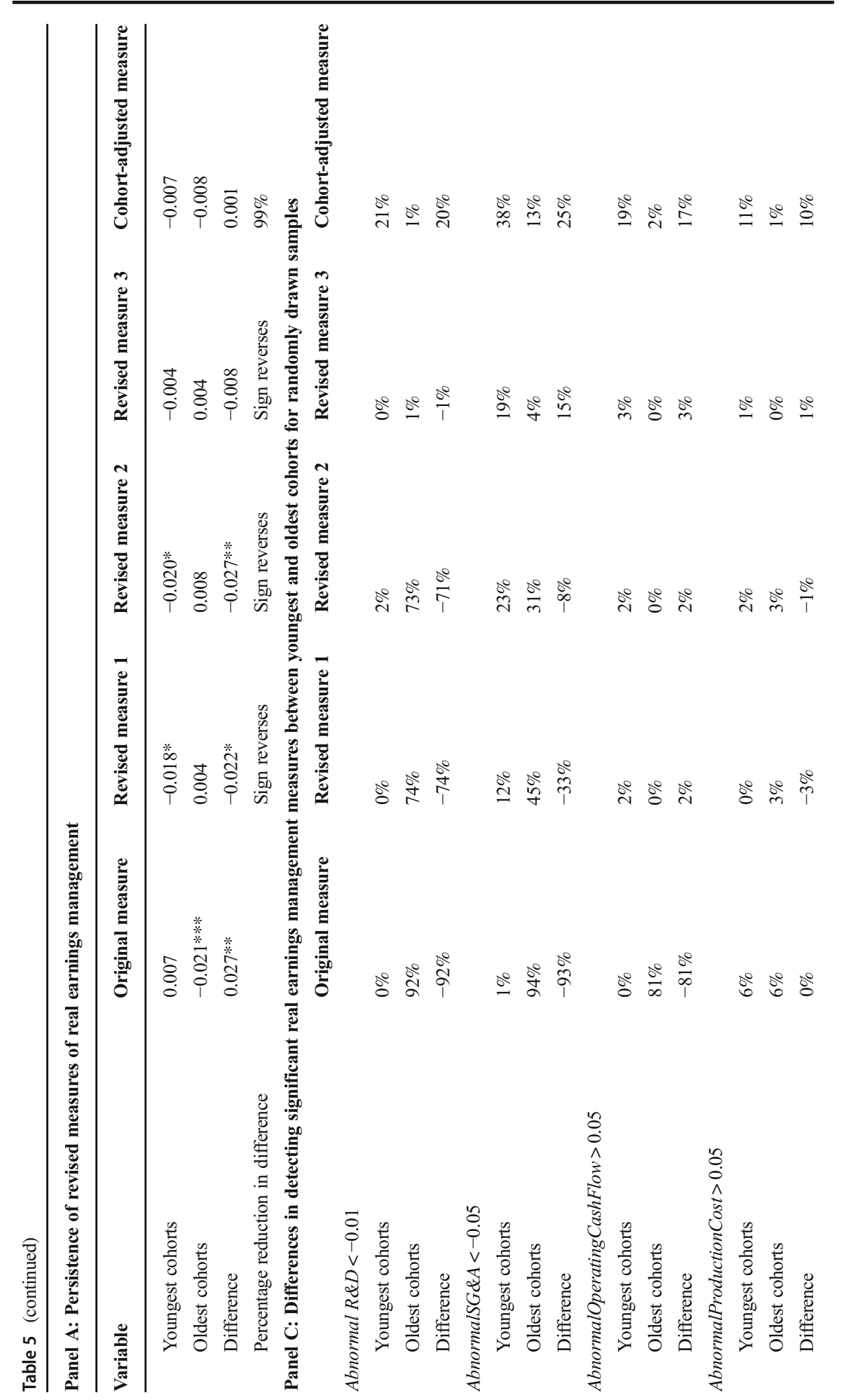




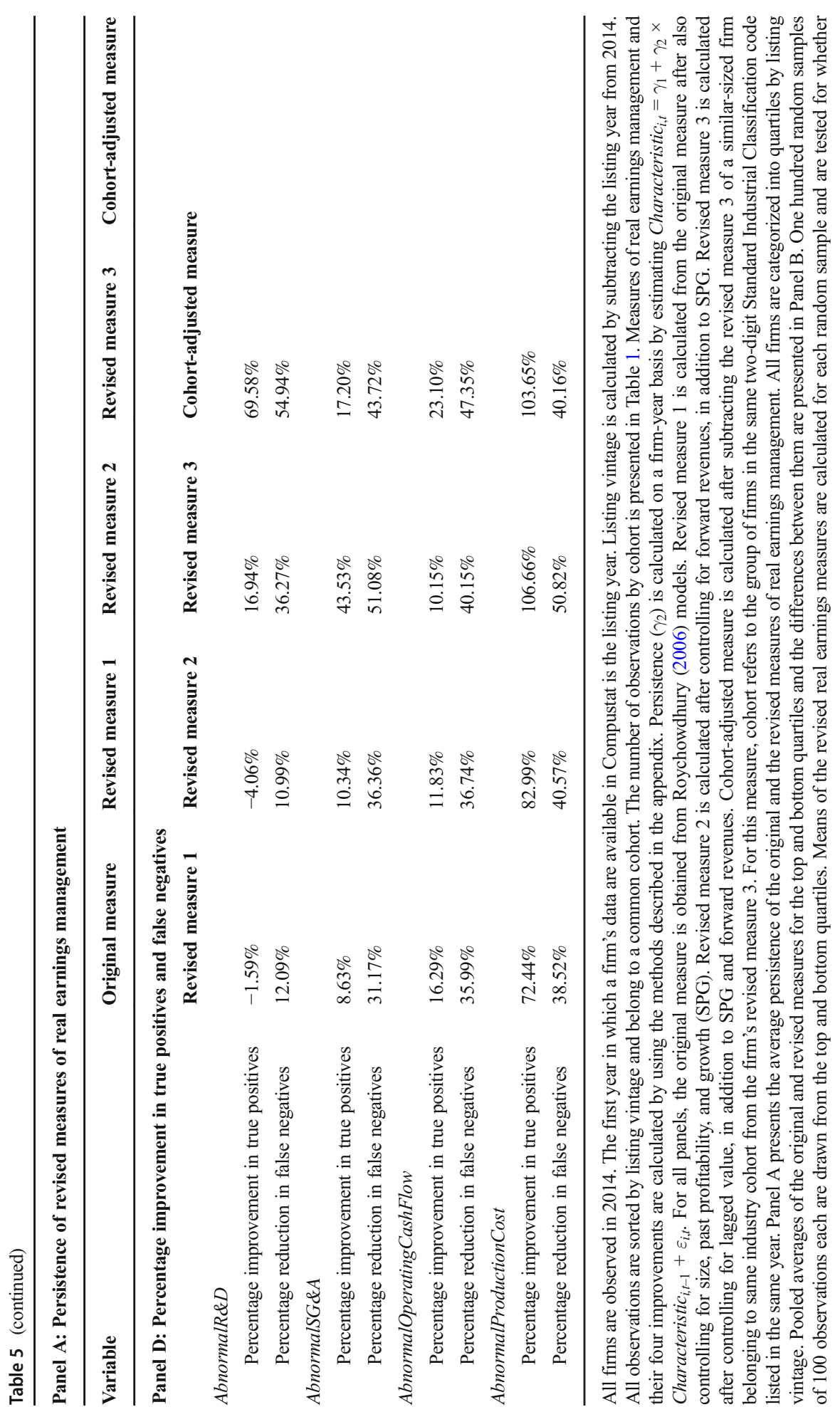




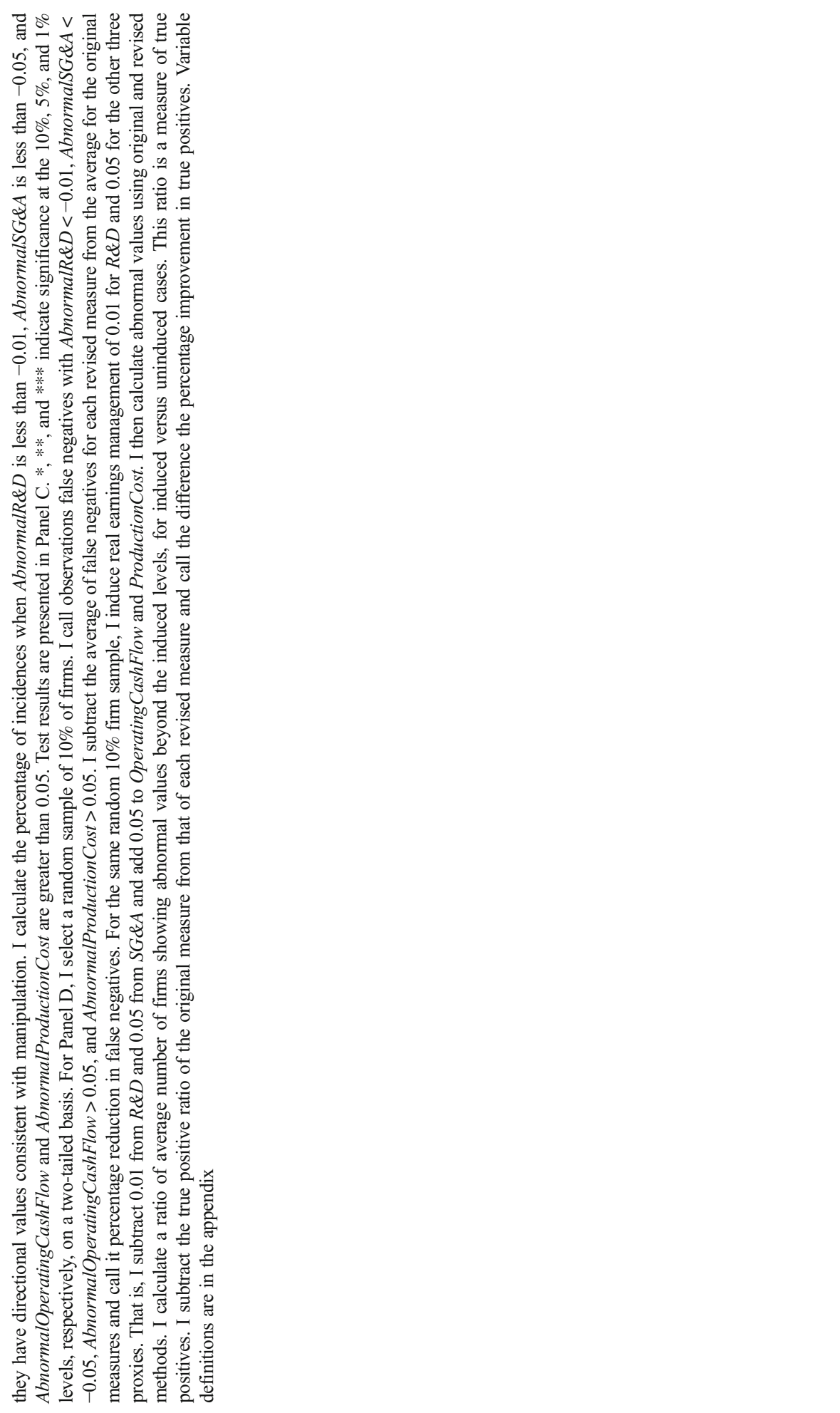


Table 6 An application of revised measures of real earnings management

\begin{tabular}{|c|c|c|c|c|c|}
\hline Variable & $\begin{array}{l}\text { Auditor } \\
\text { Resignation } \\
\text { (R) }\end{array}$ & $\begin{array}{l}\text { Auditor } \\
\text { Dismissal } \\
\text { (D) }\end{array}$ & $\begin{array}{l}\text { Continuing } \\
\text { Auditor } \\
\text { (C) }\end{array}$ & $(\mathbf{R})-(\mathrm{D})$ & $(\mathrm{R})-(\mathrm{C})$ \\
\hline \multicolumn{6}{|l|}{ AbnormalOperatingCashFlow } \\
\hline Kim and Park (2014) & -0.0996 & -0.0180 & 0.0083 & $-0.0816^{* *}$ & $-0.1079 * * *$ \\
\hline $\begin{array}{l}\text { Original measure in my } \\
\text { paper }\end{array}$ & -0.1010 & -0.0565 & 0.0147 & $-0.0445^{* * *}$ & $-0.1157 * * *$ \\
\hline Revised measure 1 & 0.0117 & -0.0134 & 0.0062 & 0.0252 & 0.0056 \\
\hline Revised measure 2 & 0.0153 & -0.0095 & 0.0058 & 0.0247 & 0.0094 \\
\hline Revised measure 3 & -0.0007 & -0.0112 & 0.0024 & 0.0105 & -0.0031 \\
\hline Cohort-adjusted measure & 0.0137 & -0.0164 & 0.0007 & 0.0301 & 0.0130 \\
\hline \multicolumn{6}{|l|}{ AbnormalProductionCost } \\
\hline Kim and Park (2014) & -0.0113 & -0.0019 & -0.0267 & -0.0094 & 0.0154 \\
\hline $\begin{array}{l}\text { Original measure in my } \\
\text { paper }\end{array}$ & -0.0903 & -0.0357 & -0.0541 & -0.0546 & -0.0362 \\
\hline Revised measure 1 & -0.0945 & -0.0375 & -0.0535 & -0.0571 & -0.0410 \\
\hline Revised measure 2 & -0.1066 & -0.0488 & -0.0489 & -0.0578 & -0.0577 \\
\hline Revised measure 3 & -0.0462 & -0.0355 & -0.0262 & -0.0107 & -0.0200 \\
\hline Cohort-adjusted measure & -0.0690 & -0.0236 & -0.0273 & -0.0454 & -0.0417 \\
\hline \multicolumn{6}{|l|}{ AbnormalSG\&A } \\
\hline Kim and Park (2014) & -0.2150 & 0.2023 & 0.1035 & $-0.4173 * * *$ & $-0.3185^{* * * *}$ \\
\hline $\begin{array}{l}\text { Original measure in my } \\
\text { paper }\end{array}$ & -0.2121 & 0.0885 & 0.0135 & $-0.3005^{* * *}$ & $-0.2256^{* * * *}$ \\
\hline Revised measure 1 & 0.0014 & -0.0247 & 0.0069 & 0.0261 & -0.0055 \\
\hline Revised measure 2 & -0.0093 & -0.0236 & 0.0050 & 0.0144 & -0.0142 \\
\hline Revised measure 3 & 0.0000 & -0.0178 & 0.0047 & 0.0179 & -0.0047 \\
\hline Cohort-adjusted measure & -0.0292 & -0.0290 & 0.0054 & -0.0002 & -0.0347 \\
\hline
\end{tabular}

This table presents the main results of Kim and Park (2014, Table 2), using the original and revised measures of real earnings management. Consistent with their study, the sample is derived from 2000 to 2010 and excludes financial firms and utilities. AuditorResignation is identified from the AUDITOR RESIGNED variable in Audit Analytics. All other auditor changes in auditors in Audit Analytics with a valid dismissal date are coded as AuditorDismissal. ContinuingAuditor represents observations that are not identified as AuditorResignation or AuditorDismissal. Real earnings management is measured by AbnormalOperatingCashFlow, AbnormalProductionCost, and AbnormalSG\&A. The last measure is multiplied by -1 to make it consistent with the direction of earnings management. The original measure is obtained from Roychowdhury (2006) models. Revised measure 1 is calculated from the original measure after controlling for size, profitability, and growth (SPG). Revised measure 2 is calculated after controlling for forward revenues, in addition to SPG. Revised measure 3 is calculated after controlling for lagged value, in addition to SPG and forward revenues. Cohort-adjusted measure is calculated after subtracting the revised measure 3 of a similar-sized firm belonging to the same industry cohort from the firm's revised measure 3 . For this measure, cohort refers to the group of firms in the same two-digit Standard Industrial Classification code listed in the same year. $* * *$, and $* * *$ indicate significance at the $10 \%, 5 \%$, and $1 \%$ levels, respectively, on a two-tailed basis. Variable definitions are in the appendix 
difference between the earnings management proxies for the two groups of companies becomes insignificant. In fact, just the inclusion of size, past profitability, and growth in the estimation models almost eliminates the difference in real earnings management proxies for the two groups. These results demonstrate that an inference regarding the presence and the extent of real earnings management studies could change if the proxies were calculated using the methods I propose.

\section{Conclusion}

This study shows that the commonly used industry-year-based models for estimating real earnings management are misspecified, because they do not control for within-industry variations in competitive strategy. As a result, wrongful inferences could be drawn about the presence of and the cause and effect relation with real earnings management, when the researcher's study variables are associated with competitive strategy.

I propose four steps to reduce competitive strategy-related measurement errors in the proxies of real earnings management. First, I include the widely accepted proxies for a firm's opportunity set of size, past profitability, and growth in the estimation model. Second, I include future revenues, because firms spend on intangibles not just for producing current revenues but also in expectation of future benefits. Third, I control for a firm's own past expenses, to identify deviations from its usual behavior in other years. Fourth, the activity of a similar-sized firm belonging to the same industry cohort is deducted from the given firm's activity to identify its abnormal activity.

I show that the implementation of the four steps significantly mitigates the measurement errors prevalent in the current proxies for real earnings management. The enhancements in models I propose should thus improve the inferences of tests involving real earnings management. Nevertheless, these enhancements would overcorrect for misspecifications if earnings management varies with the firm's opportunity set, the firm habitually manages earnings, or the members of the firm's cohort also equally manage earnings.

The thesis of this paper can be generalized to any model that estimates a firm's abnormal or manipulative behavior by difference from that of other industry players. Researchers should be cautious in interpreting their results, because that difference could represent the firm's unique competitive strategy.

Acknowledgements I thank Brad Badertscher, Jeremy Bertomeu, Sanjay Bissessur, Dirk Black, Patricia Dechow (editor), Ian Eggleton, Luminita Enache, Réka Felleg, Joseph Gerakos, Wayne Guay, Rachel Hayes, Jonas Heese, Kalin Kolev, Pepa Kraft (discussant), Scott Lee, Alvis Lo, Pablo Machado (discussant), Raj Mashruwala, Sarah McVay, Ken Merkley, Sugata Roychowdhury, Richard Sansing, Bryce Schonberger, Mani Sethuraman, Ventsislav Stamenov, Phil Stocken, Xiaoli Tian (discussant), Senyo Tse, Tony van Zijl, David Veenman, Charles Wang, Paul Zarowin, Colin Zeng (discussant), two anonymous reviewers, and the seminar participants at the 2015 annual meeting of the American Accounting Association, 2016 meeting of the European Financial Management, 2016 Tuck Accounting Conference, 2017 Financial Accounting Research sectional meeting of the American Accounting Association, University of Amsterdam, University of Baltimore, University of Calgary, University of New Hampshire, Victoria University of Wellington, and University of Nevada for suggestions that have considerably improved the paper. I also acknowledge financial support from Daniel R. Revers T'89 Faculty Fellowship at Tuck School of Business, Dartmouth College, Haskayne School of Business, University of Calgary, and Canada Research Chair program of the Government of Canada. 


\section{Appendix: Definition and measurement of variables}

\begin{tabular}{|c|c|c|}
\hline Total Assets & $=$ & AT. \\
\hline Revenues & $=$ & SALE, scaled by average total assets for the year. \\
\hline ProductionCost & $=$ & $\begin{array}{l}\text { [Cost of goods sold (COGS) + changes in inventory }(\text { INVT) }] / \text { total } \\
\text { assets at the beginning of the year. }\end{array}$ \\
\hline$S G \& A$ & $=$ & $\begin{array}{l}\text { [Selling, general, and administrative expenses (XSGA)]/ total assets at } \\
\text { the beginning of the year. }\end{array}$ \\
\hline OperatingCashFlow & $=$ & $\begin{array}{l}\text { [Cash flow from operations }(\mathrm{OANCF})] / \text { total assets at the beginning of } \\
\text { the year. }\end{array}$ \\
\hline$R \& D$ & & $\begin{array}{l}\text { [Research and development expense (XRD)] / total assets at the } \\
\text { beginning of the year; replaced by zero if XRD is missing. }\end{array}$ \\
\hline
\end{tabular}

Original measures of real earnings management (REM)

Components of ProductionCost $=$ The following equation is estimated by industry [two-digit Standard Industrial Classification (SIC) code] and year consistent with (Roychowdhury 2006, p. 365):

ProductionCost $_{i, t}=\beta_{1}+\beta_{2} \times \frac{1}{\Delta \text { Sales }_{i, t}} \underset{\text { Total }_{i, t-1} \text { Assets }}{\text { Pst }_{i,-1}}+\beta_{3} \times \frac{\text { Sales }_{i, t}}{\text { Total Assets }_{i, t-1}}$ $+\beta_{4} \times \frac{\Delta \text { Sales }_{i, t}}{\text { Total Assets }}+\beta_{5,-1} \times \frac{\Delta \text { Sales }_{i, t-1}}{\text { Total Assets }_{i, t-1}}+\epsilon_{i, t}$.

Industry-years with fewer than 15 firm-year observations are excluded. The explained portion is called the normal component (NormalProductionCost). The regression residual is called the abnormal component (AbnormalProductionCost).

Components of $S G \& A$

$=$ The following equation is estimated by industry (two-digit SIC code) and year consistent with Roychowdhury (2006, p. 365):

$S G \& A_{i, t}=\beta_{1}+\beta_{2} \times \frac{1}{\text { Total Assets }_{i, t-1}}+\beta_{3} \times \frac{\text { Sales }_{i, t-1}}{\text { Total Assets }_{i, t-1}}+\epsilon_{i, t}$.

Industry-years with fewer than 15 firm-year observations are excluded. The explained portion is called the normal component (NormalSG\&A). The regression residual is called the abnormal component (AbnormalSG\&A).

Components of OperatingCashFlow

Components of $R \& D$

Measures of real earnings
management

Market value of equity

Return on assets $(R O A)$
$=$ The following equation is estimated by industry (two-digit SIC code) and year consistent with Roychowdhury (2006, p. 365): OperatingCashFlow $_{i, t}=\beta_{1}+\beta_{2} \times \frac{1}{\text { Total Assets }_{i, t-1}}+\beta_{3} \times \frac{\text { Sales }_{i, t}}{\text { Total Assets }_{i, t-1}}$ $+\beta_{4} \times \frac{\Delta \text { Sales }_{i, t}}{\text { Total Assets }}+\epsilon_{i, t-1}$.

Industry-years with fewer than 15 firm-year observations are excluded. The explained portion is called the normal component (NormalOperatingCashFlow). The regression residual is called the abnormal component (AbnormalOperatingCashFlow).

$=$ The following equation is estimated by industry (two-digit SIC code) and year consistent with Roychowdhury (2006, p. 351, footnote 24): $R \& D_{i, t}=\beta_{1}+\beta_{2} \times \frac{1}{\text { Total Assets }, t-1_{1}}+\beta_{3} \times \frac{\text { Sales }_{i, t-1}}{\text { Total Assets } i, t-1_{1}}+\epsilon_{i, t}$.

Industry-years with fewer than 15 firm-year observations are excluded. The explained portion is called the normal component (AbnormalR\&D). The regression residual is called the abnormal component (AbnormalR\&D).

= AbnormalOperatingCashFlow, AbnormalR\&D, AbnormalSG\&A, and AbnormalProductionCost are the original measures of real earnings management.

$=[$ Market value of equity (share price $\{$ PRCC_F $\} \times$ number of shares outstanding $\{\mathrm{CSHO}\})]$. 


Total Assets $\quad=$ AT.

\begin{tabular}{|c|c|c|}
\hline & & $\begin{array}{l}\text { [Operating income after depreciation (OIADP)] / total assets at the } \\
\text { beginning of the year. }\end{array}$ \\
\hline Earning-to-price ratio $(E / P)$ & $=$ & Earnings per share (EPSFX) / share price (PRCC_F). \\
\hline Market-to-book ratio $(M / B)$ & $=$ & [Market value of equity + total liabilities $(\mathrm{TL})]$ / total assets. \\
\hline \multicolumn{3}{|l|}{$\begin{array}{l}\text { Sequential improvements in } \\
\text { REM models }\end{array}$} \\
\hline $\begin{array}{l}\text { 1. Size, profitability, and growth } \\
\text { (SPG)-adjusted measures of } \\
\text { real earnings management }\end{array}$ & $=$ & $\begin{array}{l}\text { Additional controls of market-to-book ratio, lagged return on assets } \\
\text { (ROA), and firm size (market value of equity) are included in the } \\
\text { equations to calculate the original measures. The regression residual } \\
\text { is called the revised measure (1). }\end{array}$ \\
\hline $\begin{array}{l}\text { 2. Additional control for } \\
\text { forward revenues, in addition } \\
\text { to SPG }\end{array}$ & $=$ & $\begin{array}{l}\text { Additional controls of market-to-book ratio, lagged } \mathrm{ROA} \text {, firm size } \\
\text { (market value of equity), and future revenues }\left(\frac{\text { Sales }_{i, t+1}}{\text { Total }_{\text {Asts }}, t,-1}\right) \text { are } \\
\text { included in the equations to calculate the original measures. } \\
\text { The regression residual is called the revised measure }(2) \text {. }\end{array}$ \\
\hline $\begin{array}{l}\text { 3. Additional control for lagged } \\
\text { value, in addition to SPG and } \\
\text { forward revenues }\end{array}$ & & 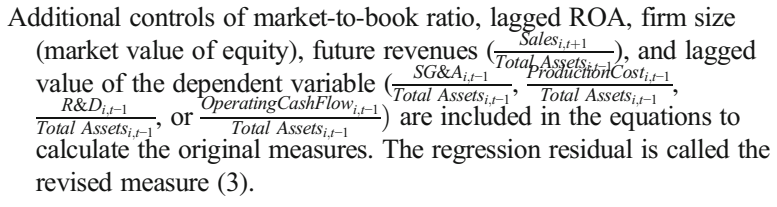 \\
\hline 4. Cohort-adjusted measure & $=$ & $\begin{array}{l}\text { Matched firms belong to the same industry and have the same listing } \\
\text { vintage as a given firm. The matched firm with the closest size is } \\
\text { called the control firm. Cohort-adjusted measure is calculated by } \\
\text { subtracting the revised measure (3) of the control firm from that of the } \\
\text { given firm. It is called the cohort-adjusted measure. }\end{array}$ \\
\hline Secondary Equity Offering & $=$ & $\begin{array}{l}\text { Secondary equity issued (SSTK) / total assets at the beginning of the } \\
\text { year. }\end{array}$ \\
\hline $\begin{array}{l}\text { Just missing earnings target } \\
\text { (SmallLoss) }\end{array}$ & $=$ & $\begin{array}{l}\text { Indicator variable that takes the value of one if the firm reports a loss and } \\
\text { the ratio of net income (IB) to beginning-of-year total assets is } \\
\text { between zero and }-1 \% \text {. }\end{array}$ \\
\hline $\begin{array}{l}\text { Just meeting earnings target } \\
\text { (SmallProfit) }\end{array}$ & $=$ & $\begin{array}{l}\text { Indicator variable that takes the value of one if the firm reports a profit } \\
\text { and the ratio of net income to beginning-of-year total assets is less } \\
\text { than } 1 \% \text {. }\end{array}$ \\
\hline $\begin{array}{l}\text { Just showing earnings growth } \\
\text { (SmallEarningsIncrease) }\end{array}$ & $=$ & $\begin{array}{l}\text { Indicator variable that takes the value of one if the firm reports an } \\
\text { increase in net income greater than zero but less than } 1 \% \text { of } \\
\text { beginning-of-year total assets. }\end{array}$ \\
\hline $\begin{array}{l}\text { Just missing showing earnings } \\
\text { growth } \\
\text { (SmallEarningsDecrease) }\end{array}$ & & $\begin{array}{l}\text { Indicator variable that takes the value of one if the firm reports a } \\
\text { decrease in net income and the decreases in absolute value is less than } \\
1 \% \text { of beginning-of-year total assets. }\end{array}$ \\
\hline
\end{tabular}

Regression variables are in italics. Compustat data items are listed in capital letters

All continuous variables are winsorized at the first and 99th percentiles

Open Access This article is distributed under the terms of the Creative Commons Attribution 4.0 International License (http://creativecommons.org/licenses/by/4.0/), which permits unrestricted use, distribution, and reproduction in any medium, provided you give appropriate credit to the original author(s) and the source, provide a link to the Creative Commons license, and indicate if changes were made. 


\section{References}

Acs, Z., \& Audretsch, D. B. (1988). Innovation in large and small firms: an empirical analysis. American Economic Review, 78(4), 678-690.

Agarwal, R., \& Gort, M. (2002). Firm and product life cycles and firm survival. The American Economic Review, 92, 184-190.

Ali, A., \& Zhang, W. (2015). CEO tenure and earnings management. Journal of Accounting and Economics, $59(1), 60-79$.

Amit, R., \& Schoemaker, P. J. H. (1993). Strategic assets and organization rent. Strategic Management Journal, 14, 33-46.

Apte, U. M., Karmarkar, U. S., \& Nath, H. K. (2008). Information services in the U.S. economy: value, jobs, and management implications. California Management Review, 50(3), 12-30.

Ayers, B. C., Lefanowicz, C., \& Robinson, J. (2002). Do firms purchase the pooling method? Review of Accounting Studies, 7(1), 5-32.

Baber, W., Fairfield, P., \& Haggard, J. (1991). The effect of concern about reported income on discretionary spending decisions: the case of research and development. The Accounting Review, 66(4), 818-829.

Baber, W., Kang, S., \& Li, Y. (2011). Modeling discretionary accrual reversal and the balance sheet as an earnings management constraint. The Accounting Review, 86, 1189-1212.

Ball, R. (2013). Accounting informs investors and earnings management is rife: two questionable beliefs. Accounting Horizons, 27, 847-853.

Banker, R. D., Huang, R., \& Natarajan, R. (2011). Equity incentives and long-term value created by SG\&A expenditure. Contemporary Accounting Research, 28, 794-830.

Barton, J. (2001). Does the use of financial derivatives affect earnings management decisions? The Accounting Review, 76(1), 1-26.

Bartov, E. (1993). The timing of asset sales and earnings manipulation. The Accounting Review, 68(4), 840-855.

Baumol, W. J., \& Schramm, C. J. (2010). Foreword. In P. P. Maglio, C. A. Kieliszewski, \& J. C. Spohrer (Eds.), Handbook of service science: research and innovations in the service economy. New York: Springer.

Benveniste, L., Busaba, W., \& Wilhelm, W. (2002). Information externalities and the role of underwriters in primary equity markets. Journal of Financial Intermediation, 11, 61-86.

Bernard, V. L., \& Stober, T. L. (1989). The nature and amount of information in cash flows and accruals. The Accounting Review, 64, 624-652.

Brickley, J., \& Zimmerman, J. (2010). Corporate governance myths: comments on Armstrong, Guay, and Weber. Journal of Accounting and Economics, 50, 235-245.

Brown, G., \& Kapadia, N. (2007). Firm-specific risk and equity market development. Journal of Financial Economics, 84, 358-388.

Bushee, B. (1998). The influence of institutional investors on myopic R\&D investment behavior. The Accounting Review, 73(3), 305-333.

Chan, L. H., Chen, K. C. W., Chen, T. Y., \& Yu, Y. (2015). Substitution between real and accruals-based earnings management after voluntary adoption of compensation clawback provisions. The Accounting Review, 90(1), 147-174.

Chemmanur, T., \& Fulghieri, P. (1999). A theory of the going-public decision. Review of Financial Studies, 12, 249-279.

Chen, X., Cheng, Q., \& Wang, X. (2015a). Does increased board independence reduce earnings management? Evidence from recent regulatory reforms. Review of Accounting Studies, 20(2), 899-933.

Chen, T., Harford, J., \& Lin, C. (2015b). Do analysts matter for governance? Evidence from natural experiments. Journal of Financial Economics, 115, 383-410.

Chen, E., Katila, R., McDonald, R., \& Eisenhardt, K. (2010). Life in the fast lane: origins of competitive interaction in new vs. established markets. Strategic Management Journal, 31, 1527-1547.

Cheng, Q., Lee, J., \& Shevlin, T. (2016). Internal governance and real earnings management. The Accounting Review, 91(4), 1051-1085.

Christensen, C. M. (1997). The innovator's dilemma: when new technologies cause great firms to fail. Boston: Harvard Business School Press.

Cohen, D., Dey, A., \& Lys, T. Z. (2008). Real and accrual-based earnings management in the pre- and postSarbanes-Oxley periods. The Accounting Review, 83(3), 757-787.

Cohen, D., Mashruwala, R., \& Zach, T. (2010). The use of advertising activities to meet earnings benchmarks: evidence from monthly data. Review of Accounting Studies, 15(4), 808-832.

Cohen, D., Pandit, S., Wasley, C. E., \& Zach, T. (2016). Measuring real activity management. Working paper. Dallas: University of Texas. 
Collins, D., Pungaliya, R. S., Vijh, A. M., \& Anand, M. (2014). The effects of firm growth and model specification choices on tests of earnings management. Working paper, University of Iowa.

Cook, T. D., \& Campbell, D. T. (1979). Quasi-experimentation: design and analysis issues for field settings. Boston: Houghton Mifflin Company.

D’Aveni, R. A. (1994). Hypercompetition: managing the dynamics of strategic maneuvering. New York: Free Press.

Dechow, P., Ge, W., \& Schrand, C. (2010). Understanding earnings quality: A review of the proxies, their determinants and their consequences. Journal of Accounting and Economics, 50, $344-401$.

Dechow, P., \& Shakespeare, C. (2009). Do managers time securitization transactions for their accounting benefits? The Accounting Review, 84(1), 99-132.

Dechow, P. M., \& Skinner, D. J. (2000). Earnings management: reconciling the views of accounting academics, practitioners, and regulators. Accounting Horizons, 14, 235-250.

Dechow, P., Sloan, R., \& Sweeney, A. (1995). Detecting earnings management. The Accounting Review, 70, $193-225$.

DeFond, M., \& Jiambalvo, J. (1994). Debt covenant violation and manipulation of accruals. Journal of Accounting and Economics, 17, 145-176.

Dhaliwal, D. S., Frankel, M., \& Trezevant, R. (1994). The taxable and book income motivations for a LIFO layer liquidation. Journal of Accounting Research, 32(2), 278-289.

Dickinson, V. (2011). Cash flow patterns as a proxy for firm life cycle. The Accounting Review, 86(6), 1969-1994.

Dopuch, N., Mashruwala, R., Seethamraju, C., \& Zach, T. (2012). The impact of a heterogeneous accrual-generating process on empirical accrual models. Journal of Accounting, Auditing and Finance, 27(3), 386-411.

Dosi, G., Nelson, R. R., \& Winter, S. G. (2000). Introduction. In G. Dosi, R. R. Nelson, \& S. G. Winter (Eds.), The nature and dynamics of organizational capabilities (pp. 1-22). Oxford: Oxford University Press.

Doyle, J. T., Jennings, J., \& Soliman, M. T. (2013). Do managers define non-GAAP earnings to meet or beat analyst forecasts? Journal of Accounting and Economics, 56(1), 40-56.

Ecker, F., Francis, J., Olsson, P., \& Schipper, K. (2013). Estimation sample selection for discretionary accruals models. Journal of Accounting and Economics, 56, 190-211.

Eisfeldt, A. L., \& Papanikolaou, D. (2013). Organization capital and the cross section of expected returns. The Journal of Finance, 68, 1365-1406.

Enache, L., \& Srivastava, A. (2018). Should intangible investments be reported separately or commingled with operating expenses? New evidence. Management Science, 64(7), 3446-3468.

Franz, D. R., HassabElnaby, H. R., \& Lobo, G. J. (2014). Impact of proximity to debt covenant violation on earnings management. Review of Accounting Studies, 19(1), 473-505.

Govindarajan, V., \& Srivastava, A. (2016). Strategy when creative destruction accelerates. Working Paper No. 2836135, Tuck School of Business, Hanover, NH.

Graham, J., Harvey, C., \& Rajgopal, S. (2005). The economic implications of corporate financial reporting. Journal of Accounting and Economics, 40(1-3), 3-73.

Guibert, B., Laganier, J., \& Volle, M. (1971). Essai sur les nomenclatures industrielles. Économie et statistique, 20, 21-36.

Gunny, K. (2010). The relation between earnings management using real activities manipulation and future performance: evidence from meeting earnings benchmark. Contemporary Accounting Research, 27(2), 855-888.

Hambrick, D. C. (1983). High profit strategies in mature capital goods industries: a contingency approach. Academy of Management Journal, 26(4), 687-707.

Hand, J. (1989). Did firms undertake debt-equity swaps for an accounting paper profit or true financial gain? The Accounting Review, 64(4), 587-623.

Healy, P. M., \& Wahlen, J. (1999). A review of the earnings management literature and its implications for standard setting. Accounting Horizons, 13(4), 365-383.

Herrmann, D., Inoue, T., \& Thomas, W. B. (2003). The sale of assets to manage earnings in Japan. Journal of Accounting Research, 41(1), 89-108.

Hribar, P., \& Collins, D. (2002). Errors in estimating accruals: implication for empirical research. Journal of Accounting Research, 40(1), 105-134.

Hribar, P., Jenkins, N., \& Johnson, W. (2006). Stock repurchases as an earnings management device. Journal of Accounting and Economics, 41(1), 3-27.

Hribar, P., \& Nichols, C. (2007). The use of unsigned earnings quality measures in tests of earnings management. Journal of Accounting Research, 45, 1017-1053.

Igami, M. (2017). Estimating the innovator's dilemma: structural analysis of creative destruction in the hard disk drive Industry, 1981-1998. Journal of Political Economy, 125(3), 798-884.

Imhoff, E. A., \& Thomas, J. K. (1988). Economic consequences of accounting standards: the lease disclosure rule change. Journal of Accounting and Economics, 100(4), 277-310.

Jackson, S., \& Wilcox, W. (2000). Do managers grant sales price reductions to avoid losses and declines in earnings and sales? Quarterly Journal of Business and Economics, 39(4), 3-20. 
Kim, Y., \& Park, M. S. (2014). Real activity manipulations and auditors' client-retention decision. The Accounting Review, 89(1), 367-401.

Kothari, S. P., Leone, A., \& Wasley, C. (2005). Performance matched discretionary accrual measures. Journal of Accounting and Economics, 39, 163-197.

Kumar, V., \& Reinartz, W. (2012). Customer relationship management: concept, strategy, and tools. New York: Springer.

Larcker, D., \& Richardson, S. (2004). Fees paid to audit firms, accrual choices, and corporate governance. Journal of Accounting Research, 42, 625-658.

Lev, B., \& Gu, F. (2016). The end of accounting and the path forward for investors and managers. Wiley Finance.

Lev, B., \& Sougiannis, T. (1996). The capitalization, amortization, and value relevance of R\&D outlays. Journal of Accounting and Economics, 21, 107-138.

McInnis, J., \& Collins, D. W. (2011). The effect of cash flow forecasts on accrual quality and benchmark beating. Journal of Accounting and Economics, 51, 219-239.

Miller, D., \& Friesen, P. H. (1984). A longitudinal study of the corporate life cycle. Management Science, 30, 1161-1183.

Owens, E., Wu, J., \& Zimmerman, J. (2017). Idiosyncratic shocks to firm underlying economics and abnormal accruals. The Accounting Review, 92(2), 183-219.

Payne, A., \& Frow, P. (2005). A strategic framework for customer relationship management. Journal of Marketing, 69(4), 167-176.

Pincus, M., \& Rajgopal, S. (2002). The interaction between accrual management and hedging: evidence from oil and gas firms. The Accounting Review, 77(1), 127-160.

Peteraf, M. A. (1993). The cornerstones of competitive advantage: a resource-based view. Strategic Management Journal, 14(3), 179-191.

Porter, M. E. (1980). Competitive strategy: techniques for analyzing industries and competitors. New York: Free Press.

Prahalad, C. K., \& Hamel, G. (1990). The core competence of the corporation. Harvard Business Review, 68(3), 79-91.

Romer, P. (1998). Bank of America roundtable on the soft revolution: achieving growth by managing intangibles. Journal of Applied Corporate Finance, 11, 8-27.

Roychowdhury, S. (2006). Earnings management through real activities manipulation. Journal of Accounting and Economics, 42(3), 335-370.

Shapiro, C., \& Varian, H. R. (1998). Information rules: a strategic guide to the network economy. Boston: Harvard Business School Press.

Siriviriyakul, S. (2015). A detailed analysis of empirical measures for real activities manipulation. Working paper. New York: City University of New York.

Sougiannis, T. (1994). The accounting-based valuation of corporate R\&D outlays. The Accounting Review, 69, 44-68.

Srivastava, A. (2014). Why have measures of earnings quality changed over time? Journal of Accounting and Economics, 57, 196-217.

Srivastava, A., \& Tse, S. (2016). Why are successive cohorts of listed firms persistently riskier? European Financial Management, 22(5), 957-1000.

Stinchcombe, A. L. (1965). Social structure and organizations. In J. G. March (Ed.), Handbook of organizations (pp. 142-193). Chicago: Rand McNally.

Thomas, L. G., \& D'Aveni, R. (2009). The changing nature of competition in the U.S. manufacturing sector, 1951-2002. Strategic Organization, 7(4), 387-431.

Treacy, M., \& Wiersema, F. (1993). Customer intimacy and other value disciplines. Harvard Business Review, 84-93.

Wernerfelt, B. (1984). A resource-based view of the firm. Strategic Management Journal, 5, 171-180.

Yip, G. S. (2004). Using strategy to change your business model. Business Strategy Review, 15(2), 17-24.

Publisher's note Springer Nature remains neutral with regard to jurisdictional claims in published maps and institutional affiliations. 